\title{
Place zabaw w mieście - dla wszystkich a nie tylko dla dzieci
}

\section{Hanna Nałęcz, Anna Ostrowska-Tryzno, Anna Pawlikowska-Piechotka}

\section{STRESZCZENIE}

Podczas gdy w przeszłości place zabaw były zazwyczaj przeznaczone tylko dla dzieci, dziś możemy obserwować więcej miejsc publicznych, terenów sportu i wypoczynku przeznaczonych dla wszystkich grup wiekowych, $\mathrm{w}$ tym osób dorosłych i w wieku podeszłym. Tradycyjne place zabaw wyposażone są w sprzęt rekreacyjny adresowany do użytkowników najmłodszych: huśtawki, zjeżdżalnie i karuzele, natomiast place zabaw o charakterze uniwersalnym mają również wyposażenie atrakcyjne dla osób dorosłych, takie jak boisko do koszykówki czy szachy. Te udogodnienia pozwalają rodzinom spędzać czas wspólnie, rozwijać koordynację fizyczną, siłę, elastyczność poczucia własnej wartości i umiejętności społeczne, a także zapewnić rekreację i przyjemność. Na podstawie publicznych placów zabaw mieszczących się w Warszawie autorzy próbowali odpowiedzieć na następujące pytania: które urządzenia pomagają pobudzać i rozwijać umiejętności społeczne, umysłowe i fizyczne oraz jakie są najczęstsze sugestie użytkowników w sprawie zmian i ulepszeń? Z wykorzystaniem badania terenowego (obserwacje uczestników, wywiady strukturalne i semistrukturalne) określono wiele czynników subiektywnych i obiektywnych, które mogłyby określić potencjał „inkluzyjnego terenu rekreacji”. Wyróżniono silne i słabe punkty placów zabaw (dostępność, lokalizację, atrakcyjność urządzeń, ich poziom bezpieczeństwa), a także oceniono relacje między zestawem urządzeń a płcią, grupą wiekową stymulacją fizyczną i psychiczną - za pomocą przyjętych kryteriów. Uniwersalne, zintegrowane place zabaw (dla zróżnicowanych grup wiekowych) powinny być dostępne dla wszystkich członków społeczności, w tym seniorów i osób niepełnosprawnych. Aby to osiągnąć, należy przestrzegać podstawowych zasad: dostępności, infrastruktury przeznaczonej dla użytkowników o różnych możliwościach fizycznych i wieku, dostosowanych do oczekiwań i zainteresowań społeczności lokalnej. Jak się okazuje, inspirujące i ekscytujące urządzenia, atrakcyjnie urządzony i dostępny teren sportu i rekreacji jest ważny, aby zachęcić do codziennej aktywności fizycznej, ma znaczenie integrujące i pomaga w zacieśnianiu więzi społecznych. Artykuł powstał na podstawie materiału badań w ramach projektu statutowego ds. -300 AWF zrealizowanego w Akademii Wychowania Fizycznego Józefa Piłsudskiego w Warszawie, dzięki dotacji grantu Ministerstwa Nauki i Szkolnictwa Wyższego.

Słowa kluczowe: rekreacja trzech generacji, dziecko w środowisku miasta, tereny rekreacji i sportu

\section{Wprowadzenie}

Od ponad stu lat, za rzecz naturalną w krajobrazie europejskich miast, uważa się wydzielone miejsca w przestrzeni publicznej przeznaczone do aktywnego wypoczynku dzieci ${ }^{1}$.

${ }^{1}$ Niniejszy tekst jest kontynuacją poprzedniego artykułu tych samych autorek, pt. Tradycje placów zabaw w Polsce i w Europie, zamieszczonego w kwartalniku MAZOWSZE Studia Regionalne, 31, 2019, s. 11-37. 
W Polsce współczesnej mamy place zabaw, które są zakładane w sąsiedztwie osiedli mieszkaniowych, szkół, przedszkoli, żłobków, dziecięcych sanatoriów i szpitali, w parkach i na terenie rodzinnych ogródków działkowych. Coraz częściej towarzyszą też innym obiektom użyteczności publicznej: instytucjom sakralnym, placówkom muzealnym, restauracjom, stacjom benzynowym, parkingom przy autostradach. Na ich podstawowe wyposażenie składają się: piaskownica, zjeżdżalnia, huśtawki, ważki, karuzele, sprężynowe bujaki i drabinki, ławeczki dla opiekunów. Statystycznie na jednym placu zabaw jest około 7 urządzeń. Naturalnie - to jest średnia; mamy w naszych miastach place zabaw „kompaktowe”, ale zarazem programowo ubogie, jedynie z 2-3 urządzeniami ustawionymi na zielonej lub buraczkowej syntetycznej wykładzinie.

Jednocześnie wiemy, że są w Polsce place zabaw z różnorodną, bogatą ofertą wielu zabawek i przyrządów gimnastycznych, zakładane na obszernym terenie, z bujną zielenią i urozmaiconymi warunkami terenowymi, na ogół - w parkach miejskich, np. w Parku Żeromskiego na warszawskim Żoliborzu. Wielką zaletą tego terenu zabaw jest rozbudowany program funkcjonalny, przewidujący zabawki dla dzieci starszych, jak wysoki pająk i ześlizg po lewej stronie i dla młodszych - jak niski kręciołek-karuzela po prawej stronie zdjęcia. Prekursorski funkcjonalnie i programowo - był to prawdopodobnie pierwszy tego typu plac zabaw w Warszawie o tak zróżnicowanym zestawieniu urządzeń (ryc. 1).

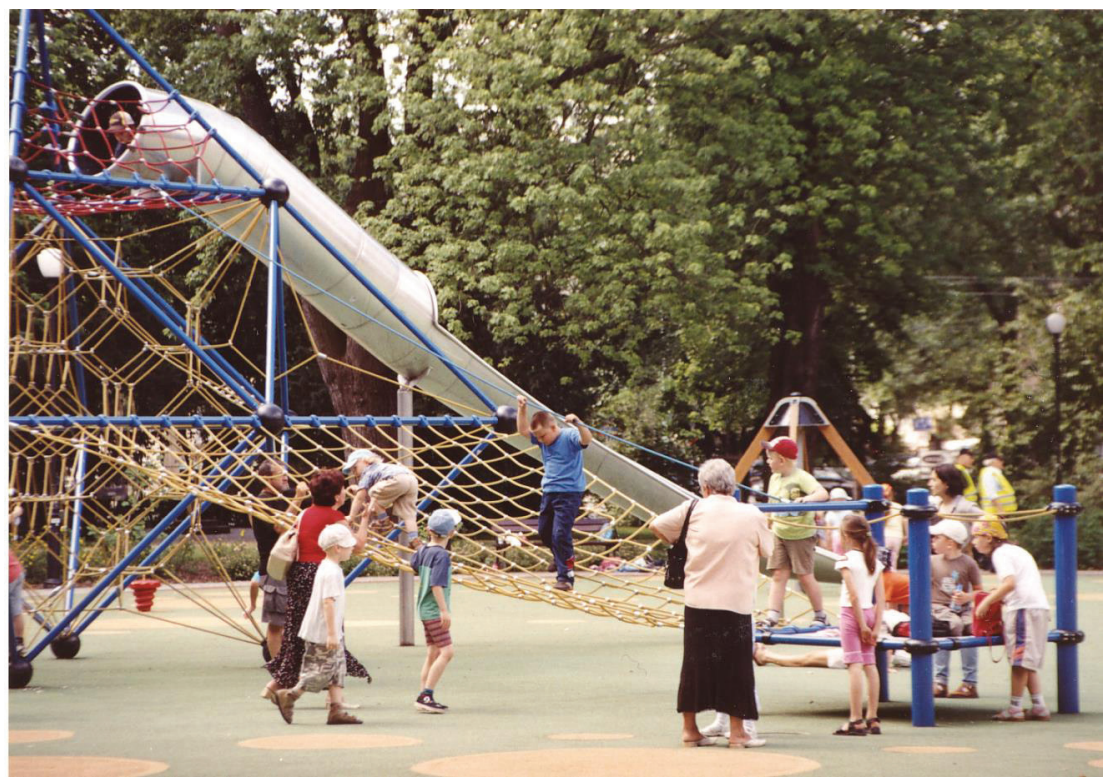

Ryc. 1. Plac zabaw w Parku Żeromskiego w Warszawie

Fot. A. Pawlikowska-Piechotka, 2019

Ostatnio powstały takie obiekty w Błoniu pod Warszawą - Miejski Park Bajka (projektu pracowni Kępka Architektura i WZA Architekci), w gminie Michałowice, w przysiółku Prawda (projekt Pracowni „,k”) oraz Podleśna Polana w Gdańsku (projekt pracownia "Qlala”). 
Wiele z nich powinniśmy już zaliczyć nie do placów zabaw, a raczej do kategorii naturalnego „parku dziecięcego" czy „ogrodu dziecięcego”, nawiązującego programowo do idei ogrodów jordanowskich zakładanych w czasach II RP i do obszernych terenowo „robinsonad” z okresu PRL [Piątkowska i in. 1976; Pomorski, Poskrobko 1998; Wirszyłło 1986].

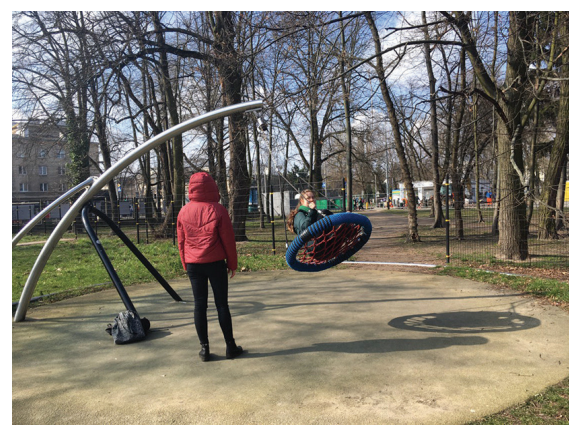

Ryc. 2. Huśtawka-koło przeznaczone dla osób w różnym wieku

Fot. A. Pawlikowska-Piechotka, 2019

Obecnie coraz donośniej nasze społeczeństwo domaga się, na wzór tendencji obserwowanych w krajach Europy Zachodniej, zamiast „placu zabaw dla dzieci” - „placu zabaw dla trzech generacji". W odpowiedzi na taką potrzebę, już powstają pierwsze eksperymentalne projekty i realizacje placów zabaw dla wszystkich grup wiekowych, w tym dzieci z niepełnosprawnością i niepełnosprawnych opiekunów. Prekursorskim przykładem jest plac zabaw dla wszystkich na terenie AWF Warszawa przy ulicy Marymonckiej 34 (ryc. 2-18). Program obiektu zakłada możliwość aktywnego wypoczynku dla trzech generacji użytkowników, a także dla dzieci z niepełnosprawnością i niepełnosprawnych opiekunów. Wielką zaletą jest, obok umieszczenia tradycyjnych urządzeń, wyznaczenie stref do gier zespołowych, ćwiczeń indywidualnych na różnym poziomie sprawności psychofizycznej, miejsc do spokojnego wypoczynku oraz altanek dla karmiących matek, zapewniających odosobnienie i prywatność. Równie interesująco zaprojektowany jest „Archeologiczny Ogród Zabaw” w Krakowie.

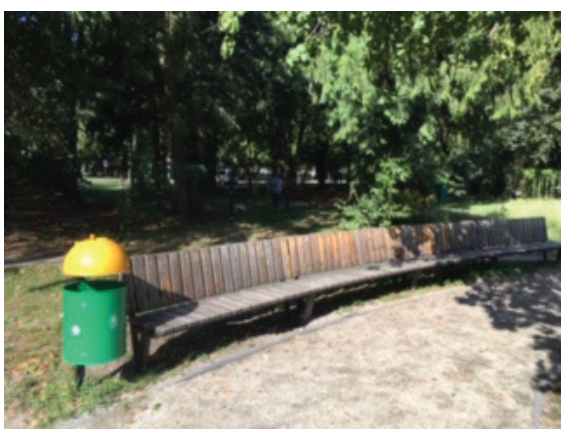

Ryc. 3. Miejsce wypoczynku

Fot. A. Pawlikowska-Piechotka, 2019

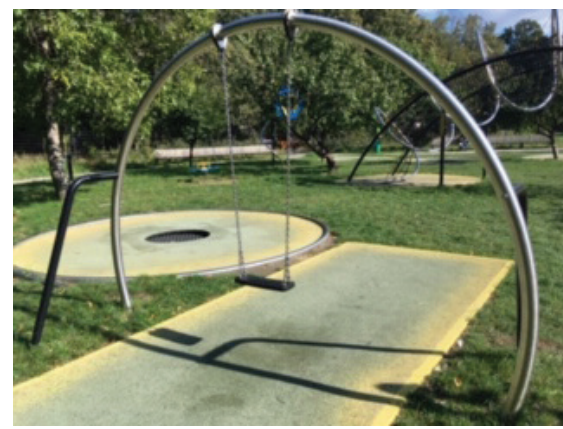

Ryc. 4. Huśtawka dla dzieci starszych Fot. A. Pawlikowska-Piechotka, 2019 
Wybór racjonalnego rozwiązania funkcjonalno-programowego dotyczącego placu zabaw „dla wszystkich” jest wypadkową wielu różnorodnych i istotnych czynników, często się nawzajem wykluczających. Z jednej strony jest uwarunkowany możliwościami terenowymi i środkami, jakimi dysponuje inwestor oraz regulacjami wynikającymi z przepisów prawa, z drugiej oczekiwaniami przyszłych użytkowników - którymi są najczęściej dzieci w wieku 3-14 lat oraz ich opiekunowie, w różnym wieku i o różnym stopniu sprawności fizycznej. Projekt musi ponadto uwzględnić warunki obiektywne: lokalizacyjne, a w tym m.in.: wielkość i ukształtowanie terenu, warunki wodno-gruntowe, orientację działki wobec stron świata, uzbrojenie w podstawowe media, dobre skomunikowanie z osiedlem mieszkaniowym, stopień insolacji terenu, kierunki wiatrów, wielkość opadów i możliwości odprowadzenia wody deszczowej, występujące rośliny i diagnozę ewentualnych silnych alergenów, jakość środowiska (hałas, zanieczyszczenia pyłowe i gazowe), estetykę otoczenia.

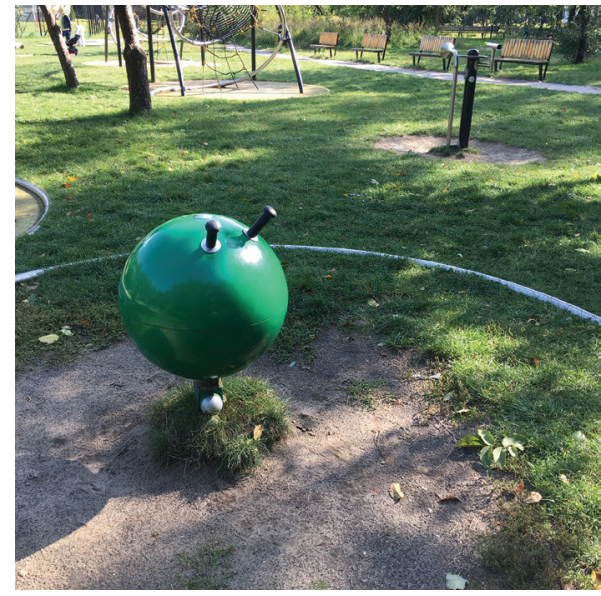

Ryc. 5. Kula-zabawka - jednocześnie urządzenie do ćwiczeń dla osób dorosłych

Fot. A. Pawlikowska-Piechotka, 2019

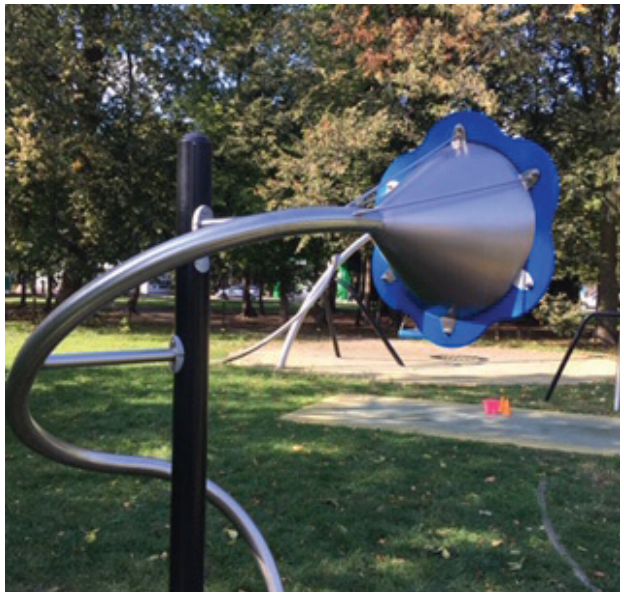

Ryc. 6. Zabawka dźwiękowa do ćwiczeń muzycznych-audio

Fot. A. Pawlikowska-Piechotka, 2019

Obecnie coraz większą uwage przywiązuje się do zapewnienia maksimum bezpieczeństwa użytkownikom placów zabaw, zapobiegania nieszczęśliwym wypadkom, które są najczęściej rezultatem wad konstrukcyjnych lub zaniedbań w konserwacji urządzeń, nieodpowiedniego podłoża lub niewłaściwego rozmieszczenia urządzeń (braku zachowania stref bezpieczeństwa). Był to zawsze problem istotny i nigdy nie lekceważony, ale obecnie dodatkowo ujęty w ramy regulacji prawnych. Polskie prawo narzuca standardy bezpiecznych urządzeń i rodzaje podłoża, (normy PN-EN 1176 oraz PN-EN 1177), z kolei same urządzenia placu zabaw podlegają formalnie normalizacjom wynikającym z dyrektywy UE nr 2001/95/ WE, w polskich regulacjach prawnych wprowadzone ustawą z dnia 12 grudnia 2003 r. o ogólnym bezpieczeństwie produktów (Dz.U. z 2003 r., nr 229 z późn. zm.). Zgodnie z zapisami prawa budowlanego place zabaw są obiektami małej architektury (zgodnie z ustawą Prawo Budowlane z dnia 7 lipca 1994 r., Dz.U. z 1994 r., nr 89 z późn. zm.). W myśl treści tej usta- 


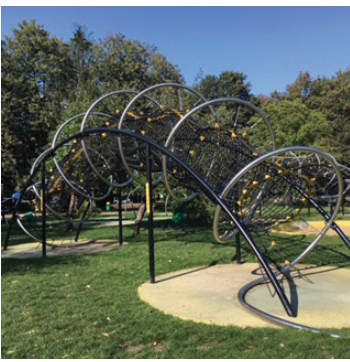

Ryc. 7. Pająk-przeplotnia

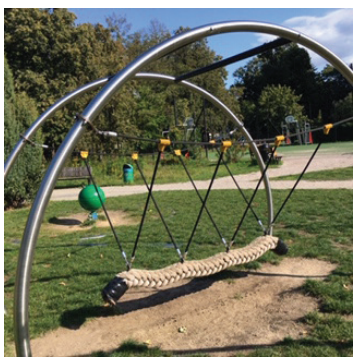

Ryc. 8. Huśtawka-gąsienica

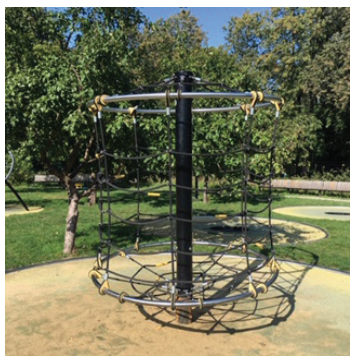

Ryc. 9. Pająk-karuzela

Fot. A. Pawlikowska-Piechotka, 2019

wy, w art. 3 pkt 4, w podpunkcie „,c wyróżniono: „obiekty służące rekreacji codziennej i utrzymaniu porządku, w tym piaskownice, huśtawki, drabinki i śmietniki”. Place zabaw są również wspomniane w regulacjach Rozporządzenia Ministra Infrastruktury w sprawie warunków technicznych, jakim powinny odpowiadać budynki i ich usytuowanie z dnia 12 kwietnia 2002 r. (Dz.U. z dnia 7 czerwca 2019 r., poz. 1065). W rozdziale 8, paragrafie 40 tego Rozporządzenia, znajdują się zapisy następującej treści w sprawie obowiązku i uwarunkowań realizacji placów zabaw przy osiedlach wielorodzinnych:

- „W zespole budynków wielorodzinnych objętych jednym pozwoleniem na budowę należy, stosownie do potrzeb użytkowych, przewidzieć place zabaw dla dzieci i miejsca rekreacji dla osób niepełnosprawnych, przy czym co najmniej 30\% tej powierzchni powinno znajdować się na terenie biologicznie czynnym, chyba że przepisy odrębne stanowią inaczej.

- Nasłonecznienie placu zabaw powinno wynosić co najmniej 4 godziny dziennie, liczone w dniach równonocy, w godzinach 10.00-16.00. W zabudowie śródmiejskiej dopuszcza się nasłonecznienie krótsze niż 2 godziny.

- Odległość placu zabaw dla dzieci, boisk dla dzieci i młodzieży oraz miejsc rekreacyjnych od linii rozgraniczających ulicę, od okien pomieszczeń przeznaczonych na pobyt ludzi oraz od miejsc gromadzenia odpadów powinna wynosić co najmniej $10 \mathrm{~m}(\ldots)^{\prime \prime}$.

W efekcie wymienionych różnorodnych uwarunkowań, racjonalne rozwiązanie zadania, jakim powinna być realizacja ciekawego i zarazem bezpiecznego placu zabaw, adresowanego do różnych grup wiekowych, zależy w dużej mierze - poza wymienionymi uwarunkowaniami zewnętrznymi - od dobrej współpracy architekta z inwestorem, ich profesjonalizmu i wyobraźni, a także od przebiegu konsultacji społecznych, czyli opinii przyszłych użytkowników.

\section{Współczesne poszukiwania programowo-funkcjonalne dla placu zabaw}

Konsekwencjami postępu cywilizacyjnego są obok korzyści których na co dzień doświadczamy i których większość z nas nie potrafi się już wyrzec, także zmiany negatywne, przede wszystkim dotykające naszego środowiska zamieszkania. Tę wysoką cenę, jaką my i przyszłe pokolenia muszą zapłacić są: stały rozrost miast (także kosztem terenów zielonych), coraz 
większe natężenie ruchu drogowego, hałas, zanieczyszczenia pyłowe i gazowe powietrza atmosferycznego, wzrost przestępczości. Rezultatem jest coraz mniej przyjazne dziecku środowisko miejskie, coraz bardziej ograniczone możliwości bezpiecznego wypoczynku na terenach otwartych, o czym w czasie ostatniej dekady alarmują coraz częściej badacze problemu z europejskich ośrodków akademickich [Rice 2009; Risotto 2012; Solarek 2017, 2019; Woolley, Lowe 2013; Woolley, Griffin 2015]. Niestety negatywne skutki urbanizacji obserwujemy także w miastach polskich i nasze dzieci nie są już w stanie swobodnie eksplorować swojego sąsiedztwa w taki sposób, jak czyniły to poprzednie generacje [Pawlikowska-Piechotka 2011].

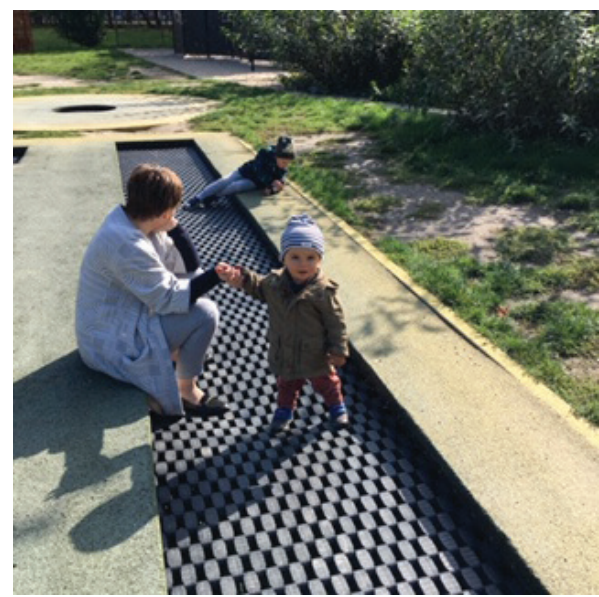

Ryc. 10. Trampoliny - bez wątpienia cieszą się największą popularnością

Fot. A. Pawlikowska-Piechotka, 2019

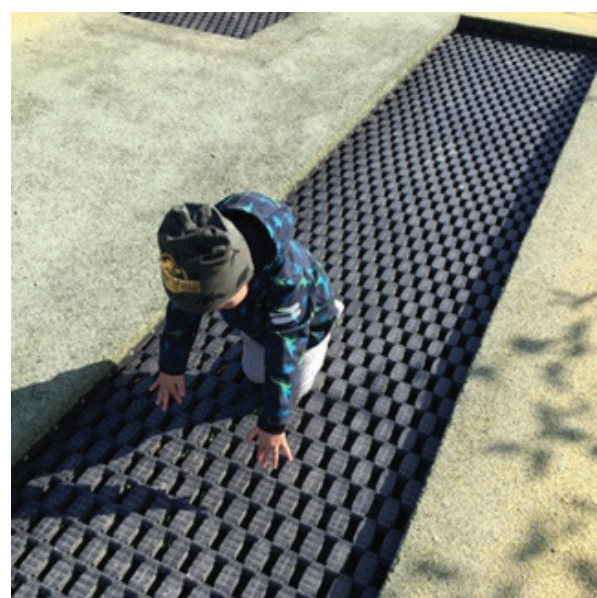

Ryc. 11. Trampolina - atrakcja dla użytkowników w każdym wieku, także dla dzieci niepełnosprawnych na wózku Fot. A. Pawlikowska-Piechotka, 2019

Zakładanie bezpiecznych, atrakcyjnie urządzonych miejsc do zabaw w pobliżu miejsca zamieszkania jest obecnie koniecznością również z innego powodu. Pedagodzy i pediatrzy są zgodni od ponad stu lat: dziecko uczy się najchętniej i najlepiej rozwija dzięki zabawie. W sposób przyjemny i niewymuszony doskonali kontakty społeczne, nawiązuje kontakty z rówieśnikami, przyswaja reguły gry zespołowej, dobre nawyki współpracy drużynowej, a przede wszystkim rozwija sprawność fizyczną. W tym kierunku też są prowadzone poszukiwania planistyczne współczesnych placów zabaw [Daly 2000; Rice 2009; Risotto 2012; Woolley, Lowe 2013; Woolley, Griffin 2015]. Taki wypoczynek na osiedlowych terenach otwartych może mieć wiele form: spacer, udział we wspólnych grach sportowych, uprawianie ogrodu, zabawa w piaskownicy lub ćwiczenia-zabawa na przyrządach. Nowością w wielu miastach europejskich jest pojawienie się w ciągu ostatnich dwóch dekad licznych placów zabaw przy budynkach użyteczności publicznej: kościołach, muzeach, bibliotekach, restauracjach i stacjach benzynowych - czyli w miejscach, w których nigdy przedtem nie były zakładane.

Różnicowanie przygotowania placu zabaw powinno także uwzględniać potrzeby dziecka, u którego obserwuje się specjalne potrzeby lub ograniczenia w zakresie któregoś 
z psychofizycznych czynników warunkujących rozwój dziecka. W myśl zasady inkluzyjności społecznej - każde dziecko powinno mieć prawo do znakomitej zabawy, kontaktu z rówieśnikami i stymulacji swojego rozwoju [Maszczak 2019; Woolley, Lowe 2013; Woolley, Griffin 2015]. To dla nich powinny być instalowane specjalne urządzenia: instrumenty i zabawki „muzyczne”, huśtawki z oprzyrządowaniem umożliwiającym mocowanie wózka inwalidzkiego, bujaki ze specjalnymi poręczami, pasami i oparciami, stolikowe piaskownice, szerokie zjeżdżalnie (dla dziecka z opiekunem) i trampoliny wpuszczone w podłoże, na które można bezpiecznie wjechać wózkiem. Pamiętanie o wyposażeniu placu zabaw w te urządzenia jest niezmiernie ważne, bo właśnie dla takiej grupy przyjemny wysiłek fizyczny, kontakt $\mathrm{z}$ rówieśnikami w warunkach swobodnej zabawy mogą być szczególnie cenne, jako istotna pomoc w rehabilitacji [Nowak 1997; Woolley 2012]. Do inkluzyjnego, uniwersalnego podejścia planistycznego w odniesieniu do przestrzeni publicznej obliguje inwestorów i projektantów szereg aktów prawnych, w tym Konstytucja RP. Jest to niezmiernie istotny segment problematyki placów zabaw i był odrębnym wątkiem naszych badań. Ponieważ jednak wymaga szerszego omówienia - to zagadnienie nie mieści się $\mathrm{w}$ ramach prezentowanego artykułu.

Jaki powinien być sam program i sposób urządzenia osiedlowego placu zabaw, tego nasze przepisy nie regulują a w gronie samych specjalistów brak zgodności. W konsekwencji poszukiwania planistyczne $\mathrm{w}$ tym obszarze i efekty inwestycyjne są za każdym razem wypadkową poczucia estetyki, ambicji, możliwości terenowych i środków, jakie można na realizację wydać - a także mody i oczekiwań przyszłych użytkowników. Z szeregu badań wy-

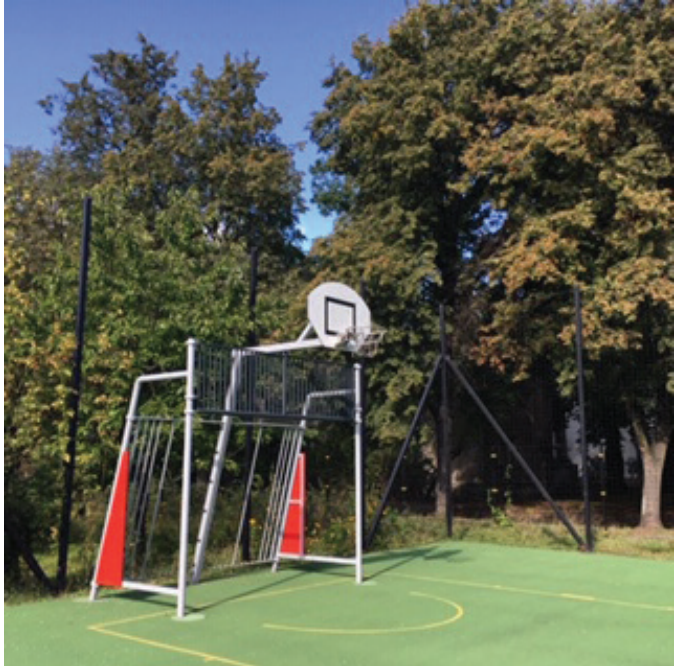

Ryc. 12. Boisko wielofunkcyjne dla młodzieży i osób dorosłych, szczególnie oblężone przez miłośników gier zespołowych w soboty, niedziele i święta

Fot. A. Pawlikowska-Piechotka, 2019 nika, że szczególnie dzieciom starszym i młodzieży najbardziej odpowiada urządzenie placu zabaw w stylu ,robinsonady" - obszernego parku przygód. Niestety jest to rozwiązanie atrakcyjne, ale jednocześnie kosztowne. Po pierwsze wymagające znacznej powierzchni (powyżej $2000 \mathrm{~m}^{2}$ ), po drugie generujące wysokie koszty utrzymania. $\mathrm{W}$ rezultacie jest możliwe do zaproponowania albo na osiedlu niezwykle luksusowym, albo na poziomie ponadosiedlowym, przy znacznym wsparciu środków zewnętrznych.

Poszukiwania coraz lepszych rozwiązań dla placu zabaw są ważne i od dziesiątków lat projekty pojedynczych zabawek i urządzeń, kompleksowego zagospodarowania placu zabaw do rekreacji przydomowej czy wielohekta- 
rowego dziecięcego parku są uważane przez architektów i rzeźbiarzy za bardzo ciekawe i niebanalne problemy do rozwiązania. Zajmowali się nim zarówno wielki wizjoner rozwoju miast w pierwszej połowie XX w. - Le Corbusier, jak i jedna z najbardziej znanych współczesnych twórców, autorka Parku Olimpijskiego w Londynie - Zaha Hadid. Naturalnie, zupełnie inny program można proponować na obszernej działce, a inny na skromnym placyku między blokami mieszkalnymi. Są to dwa różne zadania projektowe. W konsekwencji, w pracach teoretycznych i praktycznych poświęconych placom zabaw dla dzieci wyróżnia się dwa równoległe problemy:

- $\quad$ zagadnienie projektowania osiedlowych placów zabaw, w bezpośrednim sąsiedztwie miejsca zamieszkania, zakładanych na niewielkiej powierzchni: 100-300 $\mathrm{m}^{2}$ (przede wszystkim adresowanych do dzieci młodszych (0-4 lata oraz 5-10 lat),

- $\quad$ ponadosiedlowe tereny zabaw i wypoczynku dzieci starszych i młodzieży.

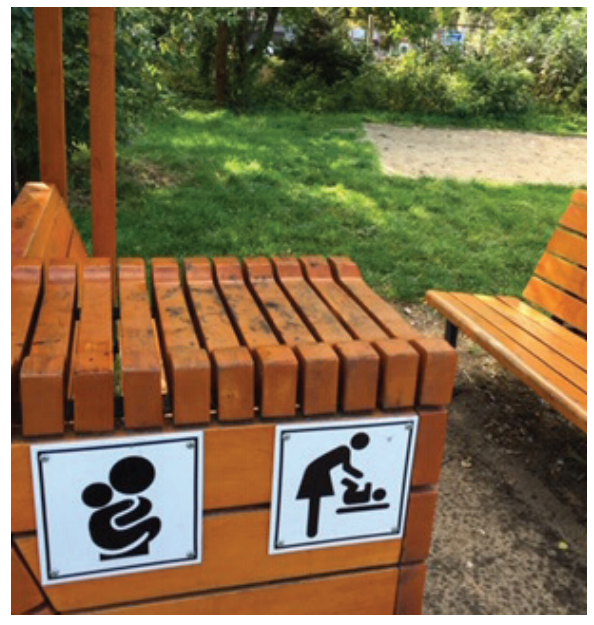

Ryc. 13. Altanka dla matek karmiących

Fot. A. Pawlikowska-Piechotka, 2019

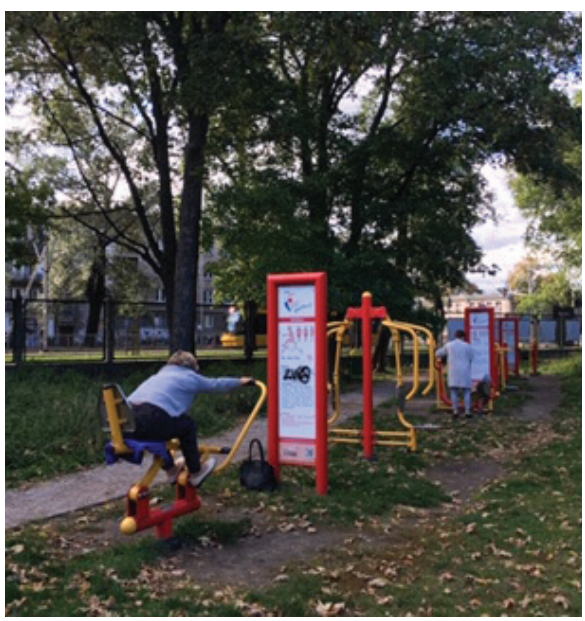

Ryc. 14. Zespół urządzeń „siłownia plenerowa” Fot. A. Pawlikowska-Piechotka, 2019

Do tej drugiej grupy będą należeć „parki dziecięce” (w tym ogrody jordanowskie, robinsonady) oraz obszerne place zabaw przy parkach miejskich i dzielnicowych terenach sportowo-wypoczynkowych, projektowane najczęściej w taki sposób, aby wszyscy członkowie wielopokoleniowej rodziny mogli wypoczywać aktywnie. Ryciny 15-18 prezentują „siłownię plenerową" dla młodzieży i dorosłych zintegrowaną z placem zabaw dla najmłodszych, zlokalizowane na terenie AWF przy ul. Marymonckiej $34 \mathrm{w}$ Warszawie. Dla zwiększenia komfortu i bezpieczeństwa użytkowników oraz efektywności ćwiczeń, przy każdym z urządzeń znajduje się tablica informacyjna, zawierająca nazwę urządzenia, prosty grafik sposobu użytkowania, opis funkcji danego urządzenia (w kolorze czarnym), instrukcję prawidłowego korzystania (w kolorze zielonym) oraz ostrzeżenia (w kolorze czerwonym).

Interesująco przedstawia się również wyposażenie placu zabaw w Parku im. Prof. Tołpy we Wrocławiu przy ul. B. Prusa, np. całoroczne zadaszenie piaskownicy i ławeczek wypo- 
czynkowych podnosi komfort zabawy i wypoczynku w dni upalne i przy lekkich mżawkach (ryc. 19).

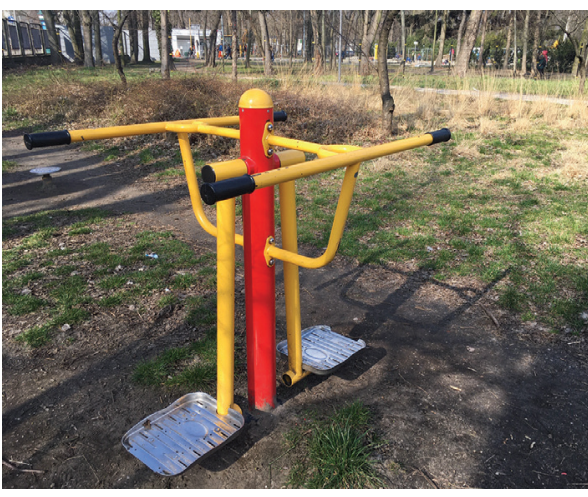

Ryc. 15. Urządzenie „Narciarz / wahadło” Funkcją tego urządzenia jest wzmocnienie siły rąk, nóg, pasa biodrowego, poprawa ruchomości stawów i polepszenie ogólnej kondycji Fot. A. Pawlikowska-Piechotka, 2020

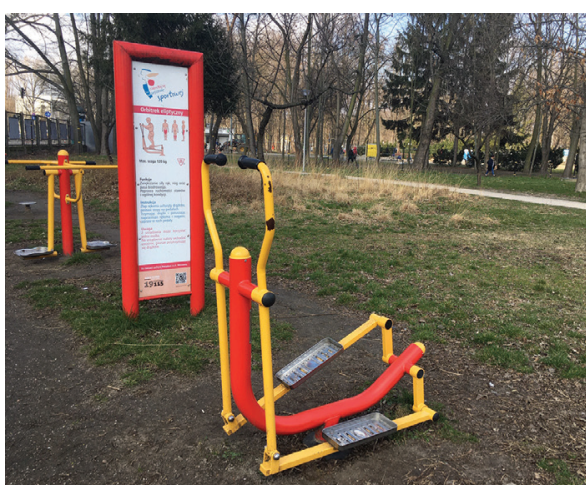

Ryc. 16. Urządzenie „Orbiterek eliptyczny" Funkcją tego urządzenia jest wzmocnienie mięśni nóg, pasa biodrowego i ramion. Poprawa wydolności układu sercowo-naczyniowego oraz oddechowego

Fot. A. Pawlikowska-Piechotka, 2020

Należy podkreślić, że „parki dziecięce” zajmują na ogół powierzchnię co najmniej 2000 m², ale górnej granicy zarówno dla wielkości terenu, jak i wydatkowanych na jego urządzenie środków praktycznie nie ma. W Europie Zachodniej założono „parki zabaw”, których koszt realizacji przekracza miliony euro (Bellville pod Paryżem, Nature Playground w Kopenhadze, Lady Diana Memorial Playground w Parku Kensington w Londynie). O tym jak niebotyczne mogą być to kwoty, o braku istnienia górnej granicy sum możliwych do wydania

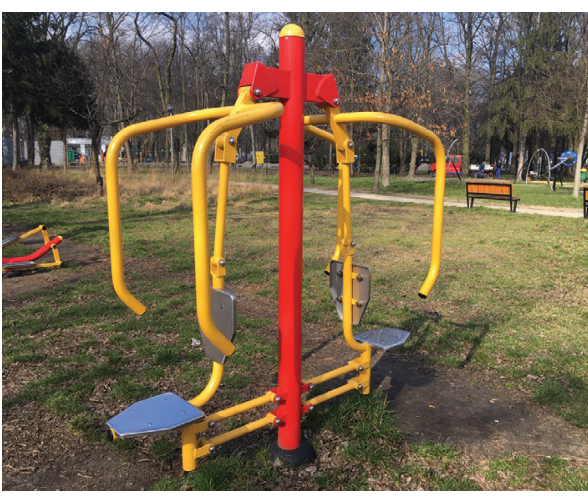

Ryc. 17. Urządzenie „Wyciskacz"

Funkcją tego urządzenia jest wzmocnienie mięśni rąk, obręczy barkowej, klatki piersiowej oraz grzbietu

Fot. A. Pawlikowska-Piechotka, 2020

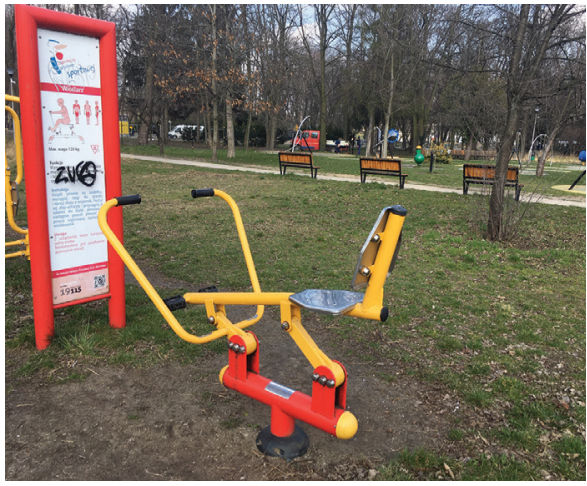

Ryc. 18. Urządzenie „Wioślarz" Funkcją tego urządzenia jest kształtowanie i wzmocnienie mięśni nóg, klatki piersiowej i brzucha oraz ogólna poprawa kondycji

Fot. A. Pawlikowska-Piechotka, 2020 


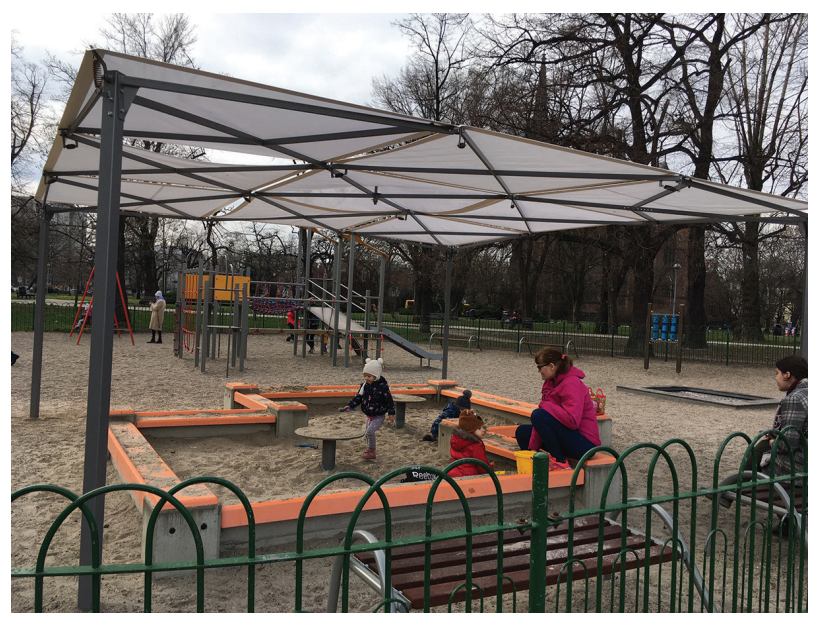

Ryc. 19. Plac zabaw w Parku im. Prof. Tołpy we Wrocławiu

Fot. A. Pawlikowska-Piechotka, 2020

na urządzenie luksusowego placu zabaw, niechaj zaświadczy przykład londyńskiego Lady Diana Memorial Playground, założonego w Parku Kensington (część Hyde Parku): obiekt pochłonął ogromne środki na budowę (1,7 mln funtów szterlingów - czyli około 9 mln złotych) oraz konieczne są stałe, znaczące wydatki na ochronę obiektu i konserwację urządzeń, ponieważ wstęp jest bezpłatny. Wspomniany londyński plac zabaw jest lubiany przez dzieci i niezmiernie popularny, stał się ponadto ciekawostką Hyde Parku i jest odwiedzany (przed godzinami otwarcia) przez licznych turystów. Niemniej, ze względów zrozumiałych trudno aby stał się, ze względu na oczywiste ograniczenia, modelem do naśladowania (ryc. 20-21).

Wśród przykładów niskobudżetowych, atrakcyjnych rozwiązań dla skromnych osiedli mieszkaniowych, można wymienić skandynawską tradycję budowania zimą lodowisk, górek saneczkowych, ze stopniami wykutymi w śniegu; budowania ze śniegu i lodu zjeżdżalni, rozmaitych zabawek - rzeźb do wspinaczki. Mało kosztownym pomysłem jest przywiezienie na plac zabaw kamieni-olbrzymów, umożliwiających zabawy i wspinaczki, jak to ma miejsce w osiedlu Camden Playgrounds w Wielkiej Brytanii. W jednym z osiedli mieszkaniowych pod Oslo zaproponowano plac zabaw z minimalną liczbą urządzeń: są tam wtopione w piaszczyste podłoże ogromne opony ciężarówek, olbrzymie głazy, stosunkowo niewielka liczba huśtawek, bujawek na sprężynie; za to bardzo dużo pustej przestrzeni do biegania, wspólnych gier. Inną, charakterystyczną cechą wyróżniającą ten plac zabaw jest brak zieleni (poza skoszoną trawą i nielicznymi drzewami z podciętymi nisko rosnącymi konarami). Powodem sa, jak twierdzą autorzy projektu, powszechne dolegliwości dzieci na tle alergicznym i w ten sposób eliminowanie przykrych alergenów oraz dbanie o bezpieczeństwo małych dzieci, które nie są w stanie bezpiecznie wspiąć się na drzewo [Gaventa 2006; Sawyer 2009].

Polskimi rozwiązaniami średniobudżetowych, ale jednocześnie niebanalnych rozwiązań są place zabaw w Krakowie (Dzikie Panty oraz Pasaż Podgórski, których zaletą jest estetyka urządzeń, a wadą monotonia i brak zieleni), w Tychach (Wodny Plac Zabaw, bardzo 
dobrze odpowiadający na zmiany klimatyczne), w Świnoujściu (Park Chopina). Należy też podkreślić, że powstające ostatnio ogrody społeczne, zakładane spontanicznie na miejskich nieużytkach (Motyka i Słońce na Jazdowie i Fort Bema w Warszawie, Ogród na Paca na warszawskim Grochowie, Ogród Centrum Reduta w Gdańsku, ogrody na Jeżycach i Wildze w Poznaniu), w swojej filozofii zakładają współudział wszystkich trzech generacji przy ich tworzeniu. Dzieci są angażowane, w miarę swoich sił i zainteresowań, do sadzenia i pielęgnacji roślin, asystowania przy opiece nad pasiekami.

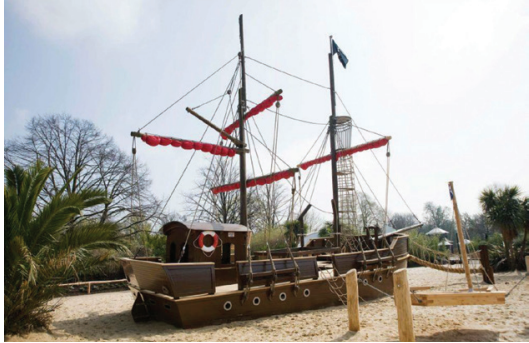

Ryc. 20. Lady Diana Memorial Playground został wzniesiony nakładem prawie 2 milionów funtów

(około 10 milionów złotych) w $2000 \mathrm{r}$.

Źródło: www.royalparks.org.uk (public domain)

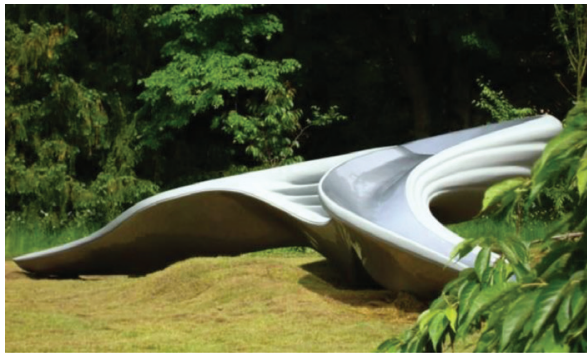

Ryc. 21. Zjeżdżalnia dla placu zabaw, zaprojektowana przez Zaha Hadid w 2004 r. dla projektu „Artist's Playground London”

Źródło: www.zahahadid.architects - za zgodą pracowni „Zaha Hadid Architects London”

Szacuje się, że obecnie w Polsce placów zabaw jest około 10 000, zajmują łączną powierzchnię ok. 600 ha (średnio mając działkę $500 \mathrm{~m}^{2}$ ), znajduje się na nich 70000 urządzeń (średnio 7 urządzeń na jednym placu). Są to w dużej mierze obiekty zlokalizowane na osiedlach wielorodzinnych, obiektach oświaty (przedszkola, szkoły), w obiektach związanych z usługami służby zdrowia (żłobki, szpitale i sanatoria dziecięce, ośrodki rehabilitacji), w parkach miejskich i na terenie rodzinnych ogrodów działkowych. Uwzględniając lokalizację i pojemność - może z nich korzystać połowa polskich dzieci. Dominują tam przeważnie skromne, podstawowe urządzenia (mała piaskownica, huśtawka, metalowa przeplotnia), stłoczone w skrajnych przypadkach na 50-100 m². Koszt urządzenia placu zabaw, bez zakupu terenu, szacuje się przeciętnie od kilkunastu tysięcy złotych (za wariant podstawowy "kompaktowy”, najtańszych i najprostszych 2-3 zabawek) do kilkudziesięciu tysięcy złotych. Górnej granicy kosztów praktycznie nie ma - może to być zarówno wydatek kilkuset tysięcy złotych, jak i kilku milionów - jeżeli pragniemy założyć już nie skromny plac zabaw, a „ogród dziecięcy” o wyjątkowo rozbudowanym programie kosztownych urządzeń2. Ze względu na finansowe ograniczenia w Polsce takich parków jest niewiele, jednym $z$ nich jest Miejski Park Bajka w Błoniu pod Warszawa który powstał w wyniku rewitalizacji zaniedbanego parku miejskiego [Pawlikowska-Piechotka 2012].

\footnotetext{
${ }^{2}$ Plac zabaw przy stawach Brustmana, planowany przez Urząd Dzielnicy Bielany w Warszawie, zgodnie ze wstępną kalkulacją ma kosztować dwa miliony złotych (źródło: www. tustolica.pl).
} 
Wydaje się jednak, że obok poszukiwań rozwiązań niebanalnych i luksusowych, bez wątpienia pociągających dla architektów rozmachem wizji i możliwościami realizacji, konieczne są przede wszystkim prace nad poszukiwaniami programowymi dla tych zwykłych, skromnych placów zabaw przy naszych osiedlach mieszkaniowych. Te obiekty są niezmiernie ważne, ponieważ umożliwiają codzienny, demokratyczny, łatwy i bezpieczny dostęp (w ciągu kilku minut od wyjścia z mieszkania, bez konieczności przekraczania ruchliwej ulicy) do terenu zabaw. Zapewniają warunek bezcenny dla prawidłowego rozwoju społecznego, fizycznego i psychicznego dziecka w każdym wieku, jakim jest aktywny wypoczynek w przestrzeni otwartej [Pellegrini, Bohn-Gettler 2013].

Wychodząc z założenia, że poznanie współczesnych oczekiwań w zakresie przygotowania i urządzenia terenów aktywnego wypoczynku może stać się istotnym narzędziem dla planowania miejskich zespołów mieszkaniowych, podjęto taki wątek badań dwukrotnie na Akademii Wychowania Fizycznego Józefa Piłsudskiego w Warszawie (ds.-114 AWF w latach 2008-2011 oraz ds.-300 AWF w latach 2016-2019). Ich celem nadrzędnym była identyfikacja uwarunkowań funkcjonalno-programowych oraz przestrzennych i społecznych zrównoważonego rozwoju terenów sportu i rekreacji w środowisku zurbanizowanym. Badania prowadzono metodą mieszaną: studiów teoretycznych (kwerenda biblioteczna, gromadzenie danych jakościowych i ilościowych wtórnych, na podstawie materiałów już opublikowanych) oraz badań terenowych (studia przypadków, gromadzenie danych ilościowych i jakościowych pierwotnych na podstawie inwentaryzacji, wywiadów strukturalizowanych oraz obserwacji jawnych). Badania terenowe prowadzono w ramach projektu statutowego ds.-114 AWF na wybranych placach zabaw Warszawy, natomiast w ramach projektu ds.-300, do materiału badań w Warszawie, dodano place zabaw położone w Modlinie i Nowym Dworze.

\section{Cel, metody i materiał badań terenowych (Warszawa, Modlin, Nowy Dwór)}

Celem podjętych badań terenowych było poznanie i porównanie sposobu urządzenia i użytkowania kilku rodzajów plenerowych placów zabaw: zlokalizowanych na terenach otwartych w parkach i ogrodach miejskich, na terenach wypoczynku osiedlowego, przy placówkach oświaty (szkoły, przedszkola) oraz przy obiektach użyteczności publicznej (restauracje, muzea, kościoły). Poza samą inwentaryzacją urządzeń i zabawek znajdujących się na placach zabaw, intencją badań było także poznanie opinii i komentarzy wyrażanych przez ich użytkowników (dzieci i ich opiekunów). Była to kontynuacja badań wcześniejszych, z lat 2008-2011, pozwalająca na identyfikację zmian w sposobie urządzania tych samych placów zabaw w Warszawie, które zaszły w ciagu ostatniej dekady.

Prace terenowe w drugim etapie (badania w latach 2016-2018) przeprowadzono w 63 obiektach plenerowych, położonych w Warszawie, Nowym Dworze oraz Modlinie, wyróżniając w materiale badawczym cztery podstawowe grupy placów zabaw:

a) place zabaw położone w parkach miejskich (w tym ogrody jordanowskie) - badania w 26 obiektach znajdujących się w Warszawie, Nowym Dworze i Modlinie, 
b) place zabaw położone na osiedlach mieszkaniowych - badania w 26 obiektach zlokalizowanych w Warszawie, Nowym Dworze i Modlinie,

c) place zabaw położone przy placówkach oświaty (przedszkola i szkoły podstawowe) - badania w 10 obiektach (5 przedszkoli, 5 szkół) w Warszawie,

d) place zabaw położone przy obiektach użyteczności publicznej (kościoły, muzea, restauracje) - 1 obiekt (kościół NMP przy ulicy Dewajtis w Warszawie).

Dobór materiału badań był podyktowany chęcią zebrania informacji i porównania placów zabaw w dużym mieście (Warszawa - powtórzony materiał badań terenowych z lat ubiegłych) oraz w miastach mniejszych (Nowy Dwór, Modlin - w tych ośrodkach uprzednio nie badano placów zabaw). Badając wybrane place zabaw (w wyżej wymienionych grupach a-d) szukano korelacji między ich: położeniem w strukturze miasta (walory środowiska, dostępność komunikacyjna, odległość od osiedli mieszkaniowych), wielkością i programem funkcjonalno-użytkowym (dobór urządzeń i ich ustawienie, znaczenie urządzeń dla stymulacji prawidłowego rozwoju psychofizycznego użytkowników, przeznaczenie urządzeń dla grup wiekowych i społecznych, informacją pre-visit oraz in situ, dostępnością dla niepełnosprawnych, stopniem bezpieczeństwa, animacją zajęć i wydarzeń) a popularnością mierzoną liczbą użytkowników, ich charakterystyką płci i wieku, długością przebywania na terenie i wyborem urządzeń, ogólną uniwersalnością i inkluzyjnością placu zabaw - jego przygotowaniem dla różnych grup wiekowych i społecznych, w tym dla osób starszych i niepełnosprawnych, organizowanymi wspólnymi zajęciami, obecnością instruktora-animatora, możliwościami zabawy wspólnej dla całej wielopokoleniowej rodziny (dziadkowie - rodzice - dzieci - wnuki), informacją dla użytkowników (pre visit oraz in situ) oraz opiniami użytkowników o atrakcyjności placów zabaw.

Wywiady strukturalizowane, wśród przebywających na terenie osób dorosłych oraz, za zgodą ich opiekunów, także wśród bawiących się tam dzieci, zostały przeprowadzone według ujednoliconego, autorskiego kwestionariusza, metodą in situ, face to face. Ogółem uzyskano 116 wypowiedzi, w czasie badań terenowych przeprowadzonych na 63 placach zabaw położonych na osiedlach mieszkaniowych (26 obiektów), w parkach miejskich (26 obiektów), przy obiektach oświaty (10 placów zabaw) oraz użyteczności publicznej (1 obiekt), położonych w Warszawie, Nowym Dworze i Modlinie ${ }^{3}$. Wywiady uzupełniono nieformalnymi rozmowami z opiekunami i dziećmi oraz obserwacjami uczestniczącymi i nieuczestniczącymi jawnymi. Dokonano też inwentaryzacji zagospodarowania i stanu obiektu na podstawie strukturalizowanych notatek oraz dokumentacji fotograficznej.

\footnotetext{
${ }^{3}$ Badania terenowe przeprowadzono w semestrze wiosennym (kwiecień - czerwiec) w 2017 r., w ramach zajęć seminarium magisterskiego (obóz naukowy) z udziałem studentów I roku studiów II stopnia Wydziału Turystyki i Rekreacji AWF Józefa Piłsudskiego w Warszawie. Kontynuowano je wiosną 2018 r. Badania terenowe prowadzono w dni powszednie, soboty, niedziele oraz święta w godzinach 10.00-18.00.
} 


\section{Wybrane rezultaty badań terenowych}

W czasie badań terenowych, obserwacji jawnych i wywiadów przeprowadzonych na wybranych placach zabaw w Warszawie, Modlinie i Nowym Dworze, zgromadzono materiał (dane pierwotne o charakterze jakościowym i ilościowym), który po uporządkowaniu i analizie był podstawą do zarysowania następującego obrazu placów zabaw w tych miejscowościach w trzech zakresach problemowych: sposób urządzenia placów zabaw, sylwetka użytkowników i sposób korzystania z placów zabaw oraz opinie i sugestie zmian wyrażone przez opiekunów i dzieci w czasie wywiadów ${ }^{4}$.

1. Sposób urządzenia placów zabaw

- Place zabaw wyglądają i są uznane przez ich użytkowników w większości za coraz bardziej bezpieczne (tylko kilka zauważonych wypadków, najczęściej niegroźnych upadków z drabinek - przeplotni lub z huśtawek), likwidowane są zabawki w złym stanie technicznym a niebezpieczne, asfaltowe nawierzchnie są zastępowane trawiastymi, syntetycznymi matami lub piaskiem, rzadziej korą (często na terenie jednego obiektu nawierzchnie są zróżnicowane). Place zabaw są najczęściej, tak jak obowiązujące przepisy wymagają ogrodzone lub znajdują się na terenie ogrodzonym (parki miejskie, wspólnoty mieszkaniowe, szkoły, przedszkola), często są oświetlone po zmroku; nieliczne mają system monitoringu CCTV (kamery). Urządzenia na placu zabaw są w dobrym stanie technicznym, czyste i solidne, kolorowe i estetyczne, uwzględniające najnowsze tendencje, nowoczesne i przemyślane, wykonane z mocnych i ładnych materiałów, że widać ogromną różnicę w zagospodarowaniu placów zabaw w stosunku do ubiegłych dekad (wyników badań terenowych z lat 2008-2011). Nie zauważono istotnych różnic między sposobem urządzenia i utrzymaniem placów zabaw w badanych miejscowościach (Warszawa, Modlin, Nowy Dwór).

- W wielu parkach miejskich powstają nowe place zabaw lub istniejące są modernizowane (Park Żeromskiego, Park Cytadela), natomiast na wielu osiedlach place zabaw są likwidowane, usuwane są urządzenia które wymagają stałego nadzoru i kontroli sanitarnych (najczęściej ofiarą padają piaskownice). Na przykład na osiedlu WSM II Żoliborz, na istniejącym od 1960 r. placu zabaw, zamieniono piaskownicę na kwietnik, natomiast zainstalowano nowe urządzenia: przeplotnię, zjeżdżalnię, huśtawki i ławeczki wypoczynkowe.

- Na placach zabaw znajduje się (w zależności od wielkości) od kilku (place osiedlowe) do kilkunastu (parki miejskie) urządzeń i zabawek. Najbardziej popularnymi są: różne rodzaje huśtawek, zjeżdżalni, bujaki-sprężynki, ścianki wspinaczkowe, przeplotnie, pająki, domki, zamki, pociągi, samochody, karuzele, piaskownice, duże klocki, zabawki edukacyjne (układanki).

\footnotetext{
${ }^{4}$ Na placu zabaw przy kościele NMP przy ulicy Dewajtis w Warszawie przeprowadzono badania terenowe w okresie 2016-2018 bez wywiadów (notatki, obserwacja jawna, nieuczestnicząca, dokumentacja fotograficzna).
} 
- Wśród badanych obiektów jedynie plac zabaw na terenie AWF w Warszawie przy ulicy Marymonckiej 34 ma urządzenia pozwalające na integrację - część zabawek (trampoliny ziemne) jest dostępna dla dzieci niepełnosprawnych na wózkach, szerokie i równe ścieżki pozwalają na swobodne poruszanie się osób z niepełnosprawnością (niepełnosprawne dzieci, niepełnosprawni opiekunowie). Jedynie plac zabaw na terenie AWF w Warszawie jest sprzężony z siłownią plenerową, umożliwiając aktywny wypoczynek młodzieży i dorosłym, w tym - opiekunom dzieci bawiących się w tym czasie na zabawkach dla nich przeznaczonych.

- Wśród badanych obiektów, jedynie w Parku Krasińskich i na terenie placu zabaw przy AWF w Warszawie znajduje się kącik (altanka) przeznaczony dla karmiącej matki; natomiast ławeczki wypoczynkowe znajdują się na wszystkich placach zabaw, przenośne toalety są umieszczane przy placach zabaw w parkach miejskich i ogrodach jordanowskich (najczęściej przenośne typu toi-toi). Jedynie w Parku Żeromskiego (dzielnica Żoliborz, Warszawa) na placu zabaw znajduje się kiosk z napojami i przekąskami ${ }^{5}$.

- Jedynie na placu zabaw przy ulicy Starej Baśni (Bielany, Warszawa) były prowadzone, zorganizowane przez Urząd Gminy Bielany, zajęcia kulturalno-edukacyjne, w maju 2017 r. „Piknik Edukacyjny” adresowany do dzieci w wieku przedszkolnym (zabawy ruchowe, konkursy, spotkania edukacyjne, eksperymenty naukowe, prezentacje pokazów sportowych i tanecznych) i do przyszłych rodziców (warsztaty masażu).

- Zdecydowanie lepiej są zagospodarowane place zabaw znajdujące się w parkach miejskich (Las Młociński, Park Żeromskiego, AWF Warszawa, Ogród Jordanowski przy ulicy Felińskiego) od położonych na osiedlach mieszkaniowych - nie ma praktycznie różnicy czy są to place zabaw istniejące od dawna (WSM Żoliborz II) czy nowo powstałe (zespół mieszkaniowy przy ulicy Rydygiera).

2. Sylwetka użytkowników i sposób korzystania z placów zabaw

- Opiekunowie z dziećmi najczęściej odwiedzają różne place zabaw w okolicy (jeżeli są takie możliwości), jak podkreślali w wywiadach: „aby wprowadzać dziecku urozmaicenie przeżyć (inne otoczenie i zabawki, inne dzieci, które spotyka)". Bywa jednak i tak, że ponieważ dzieci chętnie spotykają się i bawią w ramach tej samej grupy, opiekunowie z czasem zaczynają koordynować terminy wspólnych spotkań na placu zabaw. Z placów zabaw w parkach miejskich i na otwartych dla osób z zewnątrz osiedlach korzystają także dzieci mieszkające w okolicznych domach jednorodzinnych. Pomimo że najczęściej mają w ogródku przydomowym urządzony kącik do zabawy (piaskownica, huśtawka) - pla-

\footnotetext{
${ }^{5} \mathrm{~W}$ tym celu zaadaptowano jedną z dwóch toalet znajdujących się przy placu zabaw; z obserwacji w czasie badań terenowych wynika, że kiosk jest popularny i oblegany przez klientów, szczególnie w czasie weekendów i dni świątecznych.
} 
ce zabaw w miejscach publicznych oferuja, zdaniem ich opiekunów, ciekawsze i bardziej urozmaicone urządzenia oraz atrakcyjne towarzystwo innych dzieci. Na osiedlowe place zabaw z dobrą infrastrukturą przychodzą także dzieci z sąsiedztwa, jeżeli osiedle jest zamknięte - wówczas oficjalnym pretekstem są odwiedziny u rodziny lub znajomych. Na place zabaw opiekunowie i dzieci przychodzą najczęściej pieszo (odległość od miejsca zamieszkania do 15 minut spacerem), rzadziej korzystają ze środków transportu publicznego lub samochodu prywatnego. Wśród badanych nie było osób narzekających na brak parkingów i niedostatki transportu miejskiego. Małe dzieci (0-3) są przywożone wózkami.

- Młodsze dzieci (0-5 lat) odwiedzają plac zabaw najczęściej 2-3 razy w tygodniu $\mathrm{w}$ towarzystwie opiekuna, przebywają tam od 30 minut (jesień) do 90 minut (lato i wiosna); zimą najczęściej dzieci nie wychodzą wcale na plac zabaw; tylko kilku opiekunów zadeklarowało codzienne korzystanie z placu zabaw (jednak z wykluczeniem dni mroźnych i deszczowych), w tym wypadku było to korzystanie codzienne $\mathrm{z}$ osiedlowego placu zabaw oraz dodatkowo 1-2 razy w tygodniu wyprawy do parku miejskiego. Dzieci starsze (7-11 lat) bawią się na placu zabaw częściej, 3-4 razy w tygodniu (wychodzą przeważnie na osiedlowy plac same, bez opieki osób dorosłych), przebywają na placu zabaw krócej od dzieci młodszych, od 15 minut (zima i jesień) do 60 minut (lato i wiosna); tylko kilkoro dzieci zadeklarowało codzienne korzystanie z placu zabaw i zabawy dłuższe (do 2 godzin latem w czasie wakacji), tylko jedna osoba od 3 do 5 godzin w czasie letnich wakacji spędzanych w mieście (chłopiec, 10 lat).

- Pojedyncze urządzenia - zabawki są dla dziecka atrakcyjne przeważnie na krótko, po 3-5 minutach jest znudzone. Wówczas opiekun musi, wkraczając z pomysłami na dodatkowe animacje, wymyślać zabawy tematyczne. Dziecko chętniej i dłużej bawi się, jeżeli jest miła grupa rówieśników lub osoba dorosła organizująca wspólną dla wszystkich zabawę. Z badań wynika, że w parkach i na terenie osiedli nie więcej niż połowa opiekunów bawi się razem z dziećmi; są to najczęściej ojcowie, starsi bracia, wujkowie lub dziadkowie, rzadziej matki, starsze siostry ciocie i babki lub płatne opiekunki. Wyjątkiem - profesjonalna przedszkolanka, która zajmowała się aktywnie animacją zabaw (był to jeden przypadek odnotowany w Parku Żeromskiego, grupa 9 dzieci w wieku 3-6 lat z pobliskiego prywatnego przedszkola niemającego własnego placu zabaw).

- Dzieci w wieku 3-5 lat, bawiąc się w towarzystwie opiekunów lub rówieśników, przebywają na placu zabaw dłużej (średnio k. 45 minut). Krótki okres zabawy dzieci starszych 5-7 lat (poniżej 30 minut) wyjaśniono najczęściej brakiem atrakcji i nuda, zdecydowanie rzadziej - brakiem czasu. Ulubionymi zabawkami dzieci młodszych 3-5 lat są piaskownica (przynoszą z domu wiaderka, łopatki i foremki), bujaki na sprężynkach, zjeżdżalnia oraz zabawki „tematyczne": dom (z udziałem przyniesionych z domu pluszaków i lalek), pociąg, 
samochód, statek. Natomiast ulubionymi zabawkami dzieci starszych 5-7 lat są zjeżdżalnie, huśtawki, przeplotnie, niskie pająki i trampoliny oraz zabawki „tematyczne”: zamek, fort „dzikiego zachodu”, domek z kuchnia, pociąg, statek, samochód. Dla dzieci powyżej 7 lat atrakcyjne są rozmaite przyrządy gimnastyczne, przeplotnie, trampoliny, batuty, pająki, zjazdy na linie, ścianki wspinaczkowe, place do gier. Przy wyborze zabawek przez dzieci młodsze nie zaobserwowano istotnych różnic między dziewczynkami i chłopcami, inaczej rzecz się ma wśród dzieci powyżej 7 lat: dziewczynki wybierają najczęściej zjeżdżalnie i przeplotnie, natomiast chłopcy pająki i ścianki wspinaczkowe, mostki-równoważnie, zjazd na linie; obie grupy jednakowo chętnie wybierają huśtawki, batuty i trampoliny; przy wyborze zabawek „,tematycznych" chłopcy wybierają chętniej pociąg, samochód, statek lub palisadowy fort, dziewczynki „zameczki” i „domki”. Dzieci młodsze chętnie bawią się razem, starsze najchętniej wybierają zabawki umożliwiające zabawę indywidualną i bez pomocy dorosłych. Najmniej interesującymi zabawkami są na ogół nie tylko te w złym stanie technicznym, popsute, brzydkie, ale także wymagające pomocy dorosłych - omijane są karuzele, wymagające wspólnej zabawy z innymi dziećmi namalowane fabrycznie na wykładzinie klasy, „kółko i krzyżyk”, szachownice; mało popularne są także niskie ścianki wspinaczkowe i przeplotnie „drabinki” (do $150 \mathrm{~cm}$ ) przeznaczone dla małych dzieci. Młodsze dzieci przynoszą na place zabaw swoje zabawki: pluszaki, łopatki, foremki, wiaderka, samochodziki i lalki; dzieci starsze - rowery, hulajnogi, kometki, wrotki i piłki.

- W czasie badań terenowych zauważono, że użytkownikami osiedlowych placów zabaw są w dni powszednie najczęściej opiekunowie z małymi dziećmi (w wieku 0-5 lat), natomiast w czasie badań prowadzonych w soboty i niedziele odnotowano wzrost obecności dzieci w wieku wczesnoszkolnym (w wieku 6-11 lat). Dzieci młodsze (w wieku do 7 lat) przebywają na placu zabaw w towarzystwie opiekuna (rodzice, dziadkowie, wynajęta opiekunka ${ }^{6}$ ), często starszego rodzeństwa. W czasie dni powszednich wśród opiekunów dzieci na placach zabaw przeważają kobiety (matki, ciocie, babcie, wynajęte opiekunki $\mathrm{w}$ różnym wieku), natomiast $\mathrm{w}$ dni świąteczne - są prawie równe proporcje opiekunów wśród kobiet i mężczyzn.

- Z Z naszych obserwacji wynika, że wielu opiekunów dzieci obserwuje nie tylko swoich podopiecznych, ale ma nawyk stałego skanowania wzrokiem otoczenia placu zabaw. Zachowują się czujnie i nieufnie wobec sytuacji podejrzanych, informują nawzajem o spostrzeżeniach i niebezpieczeństwie, biorą czynnie

\footnotetext{
${ }^{6}$ Żaden z dorosłych towarzyszących dziecku na placu zabaw, spośród biorących udział w wywiadzie przeprowadzonym $\mathrm{w}$ ramach projektu badawczego, nie przyznał się do bycia płatnym opiekunem. Jednak z obserwacji uczestniczących prowadzonych w czasie badań terenowych wiadomo, że płatni opiekunowie dzieci w wieku 0-6 nie należą do rzadkości (wśród nich także rosyjskojęzyczne młode i w średnim wieku kobiety).
} 
udział w dbaniu o bezpieczeństwo (na przykład od razu interweniuja kiedy jakieś dziecko wchodzi „pod prąd” na zjeżdżalnię). Uczestnicy badań odczuli te zachowania przy próbach dokumentacji fotograficznej bawiących się dzieci (spotykało się to najczęściej z gwałtownym protestem ze strony ich opiekunów, nawet oskarżeniami o niecne zamiary) ${ }^{7}$.

- Opiekunowie dzieci przynoszą ze sobą napoje (soki, napoje „smakowe”, woda, herbatki), owoce (jabłka, pomarańcze i banany), kanapki z wędliną lub serem, słodycze (czekolada, batony, cukierki, herbatniki, ciastka), słone paluszki oraz chipsy. W czasie wywiadów nie pojawiły się sugestie na temat braku usług handlu i gastronomii na placu zabaw lub w jego pobliżu - kawiarni i kiosku z napojami i słodyczami.

3. Opinie użytkowników i sugestie wprowadzenia zmian w celu poprawy programu placów zabaw

- Ogółem niezadowolonych z warunków rekreacji na terenach zielonych, położonych w pobliżu miejsca zamieszkania, było ponad 50\% osób ankietowanych mieszkańców Warszawy, Nowego Dworu i Modlina. Najczęściej narzekano na zbyt skromnie urządzone i na zbyt małej powierzchni położone osiedlowe place zabaw, a także na zbyt skromną zieleń, brak zadbanych trawników, nasadzeń drzew i krzewów, estetycznych klombów z kwiatami. Należy podkreślić, że jednocześnie zdarzały się także postulaty usuwania krzewów i nisko rosnących gałęzi drzew z uwagi na zagrożenie ze strony kleszczy. Zwracano również uwagę na brak toalet przy placach zabaw znajdujących się w parkach miejskich (jest ich brak lub są zdewastowane i brudne - np. plac zabaw w Parku Cytadela). Być może, jak sugerowano, specjalnie przeznaczone dla małych dzieci stałe lub przenośne toi-toi, uchronią te urządzenia przed dewastacją będą nie tylko bezpieczniejsze, ale i dla dzieci bardziej komfortowe, pozwolą zachować właściwe standardy sanitarne.

- Osobami mającymi uwagi krytyczne były najczęściej te osoby, które 1 lub 2 razy w tygodniu decydują się na wyprawę z podopiecznymi do odległego od domu, ale atrakcyjnego dla dzieci placu zabaw, położonego najczęściej w parku dzielnicowym, w odległości średnio około 1,0-1,5 km od stałego miejsca zamieszkania. Jest to wówczas wyprawa środkami komunikacji publicznej (izochrona dojazdu wraz z dojściem od przystanku 10-15 minut) lub samochodem (izochrona dojazdu wraz z dojściem od parkingu 5-10 minut). Wówczas czas przebywania na placu zabaw oceniony jest na około 45 minut (łącznie z ewentualnym spacerem po parku i dojazdem z domu - na ponad 90 minut).

\footnotetext{
${ }^{7}$ Zgodnie z obowiązującym regulaminem Lady Diana Memorial Playground w Kensington Park (część Hyde Park położonego w centrum Londynu) na terenie placu zabaw wolno przebywać wyłącznie osobom dorosłym, które towarzyszą tam dzieciom. Turyści są wpuszczani na teren obiektu wyłącznie na okres 30 minut przed otwarciem placu zabaw i stanowczo proszeni o jego opuszczenie przed wejściem tam dzieci z opiekunami.
} 
- Użytkownicy, proszeni o wyrażenie opinii na temat oczekiwań w stosunku do poprawy infrastruktury placów zabaw, podkreślali wagę obszernego, zielonego terenu w pobliżu miejsca zamieszkania (aby, cytując najczęstsze wypowiedzi opiekunów, dzieci miały gdzie pobiegać), różnorodne przyrządy pozwalające na urozmaicone ćwiczenia i będące atrakcyjnymi dla zróżnicowanych grup wiekowych oraz czyste i estetyczne toalety. Najczęściej wymieniano wśród pożądanych urządzeń: dla dzieci młodszych duże klocki i układanki logiczne, dla starszych pająki i zjeżdżalnie „spiralki”, „małpie mostki”, ścieżki spacerowe i rowerowo-wrotkowe/rolkowe, urządzenia do ewolucji na deskorolce (mini skate-park), stoły do gry w ping-ponga, bezpieczne i atrakcyjne huśtawki - kosze, siłownie plenerowe oraz place do gier wspólnych. Zwracano uwagę na konieczność ochrony piaskownicy po zmroku (są dostępne piaskownice z daszkiem przeciwsłonecznym - wieczorem zsuwanym jako pokrywa piaskownicy). Często sugerowano założenie wypożyczalni sprzętu sportowego przy parkach miejskich (rowerów, hulajnóg, badmintona, piłek), instalowanie siłowni plenerowych przy placach zabaw (atrakcyjnych dla osób dorosłych i dzieci starszych), dbania o zieleń ${ }^{8}$.

- Zwracano uwagę na brak sezonowych atrakcji. Podkreślano, że wobec braku mroźnych, z pokrywą śnieżną i ujemnymi temperaturami zim, coraz mniej ważne są górki saneczkowe i lodowiska, a bardziej oczekiwane są brodziki wobec stale zwiększającej się liczby dni upalnych późną wiosną i latem.

- Odpowiednio impregnowane zadaszenia, na co zwracano uwagę, mogą także chronić w czasie krótkotrwałych, niewielkich mżawek. Innymi ważnymi propozycjami dla działań ochronnych przed nadmiernym przegrzaniem się dzieci w dni upalne, była sugestia instalowania brodzików i fontann.

- Wobec ostrzeżeń sanitarnych dotyczących obecności kleszczy i komarów, zwracano uwage na konieczność opryskiwania krzewów i traw rosnących wokół placów zabaw, dla zwiększenia bezpieczeństwa opiekunów i dzieci wprowadzenia tablic informacyjnych o tym zagrożeniu. Innym postulatem było wskazanie na konieczność badań syntetycznych wykładzin (obawy na podstawie doniesień prasowych o ich możliwej wysokiej toksyczności).

- Sugerowano umieszczenie większej liczby tablic informacyjnych przy wejściu na plac zabaw, nie tylko z numerami telefonów alarmowych, ale ostrzegających i zakazujących określonych zachowań, takich jak wprowadzania psów na plac zabaw, korzystania z zabawek niezgodnie z ich przeznaczeniem, wchodzenie pod prąd na zjeżdżalnię, podchodzenie zbyt blisko do huśtawek. Kolejną

\footnotetext{
${ }^{8}$ Jednocześnie w czasie naszych badań terenowych, przeprowadzonych wśród użytkowników siłowni plenerowych, wśród sugestii wprowadzania ulepszeń funkcjonalno-programowych wymieniano zasadność budowy także urządzeń dla dzieci młodszych, typowych dla placu zabaw (piaskownica, bujaki-sprężynki) - co dowodzi zasadności łączenia ze sobą tych obiektów.
} 
propozycja, zgłaszaną w czasie badań terenowych, była instalacja przy wejściu na plac zabaw, obok tradycyjnej tablicy z regulaminem i telefonami alarmowymi, także dodatkowej tablicy świetlnej (może wzbogaconej aplikacją QR), informującej o aktualnych kwestiach bezpieczeństwa, takich jak stan środowiska, warunki pogodowe, alarmy i ostrzeżenia przed spodziewanymi nagłymi zmianami pogody, stopień zanieczyszczenia powietrza (zanieczyszczenia pyłowe, gazowe, alergeny, hałas), a także z informacjami o planowanych imprezach sportowych i kulturalnych, okolicznościowych festynach, zorganizowanych pokazach, zabawach i konkursach.

- W czasie wywiadów opiekunowie dzieci zwracali uwagę na zasadność zamontowania monitoringu (CCTV, kamery) oraz stałych dyżurów ochrony lub straży miejskiej, nawet okresowych patroli policji - wobec pojawiających się osób w stanie nietrzeźwym, zachowań chuligańskich, dewastacji urządzeń, zaśmiecania terenu (w tym potłuczonymi butelkami po napojach alkoholowych, brudnymi prezerwatywami), wyprowadzania psów bez sprzątania po nich.

Z analizy zebranego w czasie badań terenowych materiału wynika, że krótki okres przebywania na placu zabaw (średnio ok. 30 minut w czasie ciepłych, bezdeszczowych i słonecznych dni wiosny 2017 i 2018 r.) ogólnie wskazuje na brak nawyku dłuższej, codziennej aktywności fizycznej. Wynika to raczej z braku atrakcji na osiedlowym placu zabaw niż z braku czasu, ponieważ wiele osób decyduje się na wyprawę do parku miejskiego w sąsiedniej dzielnicy, aby dziecko mogło bawić się w bardziej inspirujących warunkach. W rezultacie, na przykład na placu zabaw na terenie AWF w Warszawie przy ulicy Marymonckiej 34, bawią się dzieci także z odległych osiedli. Podobnie jest na placu zabaw w Parku Żeromskiego przy placu Wilsona oraz w Ogrodzie Jordanowskim przy ulicy Felińskiego, dokąd przyjeżdżają opiekunowie z dziećmi nawet z dzielnic sąsiednich. Zabawki tam zainstalowane są oblegane, do najbardziej atrakcyjnych (na przykład pająka ze zjeżdżalnią) w pogodne dni świąteczne tworzą się kolejki.

Opiekunowie stosunkowo rzadko bawią się wspólnie z dziećmi, pomimo że takie zabawy są przez dzieci cenione. Z naszych obserwacji wynika, że częściej bawią się z dziećmi ojcowie (dziadkowie, wujkowie) niż opiekunki kobiety (mamy, ciocie, babcie, opiekunki płatne). Wyjątkiem są korzystające z publicznych placów zabaw prywatne przedszkola, tam opiekunki-wychowawczynie inicjują zabawy i same biorą w nich udział. Zatem, być może dobrym rozwiązaniem byłoby (szczególnie cennym dla dzieci nieobjętych wychowaniem przedszkolnym) zainicjowanie przy popularnych placach zabaw w parkach miejskich wspólnych zajęć zorganizowanych. Mogłyby mieć miejsce w wybrane dni tygodnia, o stałej porze, być skierowane do dzieci w różnych grupach wiekowych oraz ich opiekunów, przy udziale profesjonalistów - animatorów, absolwentów pedagogiki i specjalistów sportu i rekreacji z AWF, organizowane przy wsparciu samorządów lokalnych. Udane doświadczenia w tym zakresie ma już Urząd Dzielnicy Bielany w Warszawie.

W czasie badań terenowych, uwagę zwróciły budzące duże wątpliwość nawyki żywieniowe, rodzaj deklarowanych napojów i przekąsek przynoszonych na plac zabaw jako dru- 
gie śniadanie lub podwieczorek (niepokojący duży udział napojów słodzonych i słodyczy, słonych przekąsek). Chociaż takich sugestii wśród ankietowanych nie było, być może na przykład kiosk „,zdrowa przekąska” na placu zabaw, z ofertą promującą zdrowa, zbilansowaną żywność, ulotki informacyjne i edukacyjne, pomógłby opiekunom lepiej przygotować drugie śniadanie lub podwieczorek dla dzieci, bez konieczności przynoszenia wszystkich produktów z domu.

\section{Zakończenie}

Coraz powszechniej doświadczane zmiany naszego stylu i tempa życia są widoczne także w sposobie wypoczynku i wyborze codziennych form aktywnej rekreacji na terenach miejskich osiedli mieszkaniowych. Tak jak oczekujemy coraz wyższych standardów naszego środowiska zamieszkania, usług w dziedzinie zdrowia, oświaty, handlu - mamy także coraz bardziej sprecyzowane oczekiwania w stosunku do terenów wypoczynku i sportu w pobliżu miejsca naszego zamieszkania, w tym do placów zabaw dla dzieci. Oczekiwania te wiążą się najczęściej z potrzebą wypoczynku dziecka i jego opiekunów w środowisku zdrowym, bezpiecznym, estetycznym, położonym blisko domu. Ważne jest, aby były tam dostępne urządzenia (zabawki, przyrządy gimnastyczne) pozwalające na atrakcyjne i różnorodne formy rekreacji aktywnej, dostosowane do wieku, kondycji fizycznej i zainteresowań. Ponadto, wielu współczesnych mieszkańców miast postuluje uniwersalny sposób zagospodarowania terenów sportu - pozwalających na aktywny wypoczynek i zabawę wspólną - wszystkich członków rodziny, o różnych zainteresowaniach i stopniu sprawności fizycznej (placów zabaw dla trzech generacji) (tabela 1 ).

Tabela 1. Formy rekreacji i proponowane rodzaje urządzeń dla uniwersalnego placu zabaw (grupy wiekowe / formy rekreacji / odpowiednie urządzenia)

\begin{tabular}{|c|c|c|}
\hline Grupa wieku & Forma rekreacji & Rodzaj urządzeń \\
\hline $\begin{array}{l}\text { Dzieci małe } \\
\text { (3-5 lat) }\end{array}$ & $\begin{array}{l}\text { zabawy ruchowe } \\
\text { pod opieką osób } \\
\text { starszych, bieganie } \\
\text { na niewielkie } \\
\text { odległości, zabawy } \\
\text { w piaskownicy, } \\
\text { zabawki edukacyjne }\end{array}$ & $\begin{array}{l}\left.\text { piaskownica (ok. } 20 \mathrm{~m}^{2}\right) \text {, brodzik-fontanna, stołeczki } \\
\text { i ławki dla opiekunów, niskie huśtawki i bujaki na } \\
\text { sprężynkach, karuzele, zabawki tematyczne (domki, } \\
\text { pociągi, samochody), duże klocki i układanki } \\
\text { - urządzenia chronione latem płóciennym } \\
\text { zadaszeniem, place trawiaste do kąpieli słonecznych } \\
\text { i pikników, świetlica (sala rekreacyjna, kawiarnia } \\
\text { z toaleta, wypożyczalnia zabawek), ławeczki do } \\
\text { wypoczynku, stoliki, oświetlenie }\end{array}$ \\
\hline
\end{tabular}




\begin{tabular}{|c|c|c|}
\hline Grupa wieku & Forma rekreacji & Rodzaj urządzeń \\
\hline $\begin{array}{l}\text { Dzieci starsze } \\
\text { (5-11 lat) }\end{array}$ & $\begin{array}{l}\text { zabawy zespołowe, } \\
\text { zręcznościowe, } \\
\text { edukacyjne } \\
\text { układanki logiczne, } \\
\text { współzawodnictwo, } \\
\text { gry zespołowe, } \\
\text { jazda na rowerze, } \\
\text { wrotkach, łyżwach, } \\
\text { sankach, nartach }\end{array}$ & $\begin{array}{l}\text { piaskownica }\left(100 \mathrm{~m}^{2}\right) \text {, brodzik-fontanna, duże } \\
\text { klocki typu lego, układanki logiczne, zabawki } \\
\text { edukacyjne (w tym sonarowe), przeplotnie, huśtawki, } \\
\text { "małpie mosty", zjeżdżalnie, karuzele, przyrządy } \\
\text { gimnastyczne, ścianka wspinaczkowa, pająi, } \\
\text { trampoliny i batuty, beczka-kręciołek, plac do gier } \\
\text { wspólnych, ścieżka rowerowa i mały skate park do } \\
\text { prostych ewolucji, lodowisko, górki saneczkowe, } \\
\text { kąpielisko (płytki brodzik), zabawki tematyczne } \\
\text { (statek piratów, indiańska wioska, zameczek), miejsca } \\
\text { do pikników, świetlica (sala rekreacyjna, kawiarnia } \\
\text { z toaleta, wypożyczalnia zabawek), ławeczki do } \\
\text { wypoczynku, stoliki, oświetlenie }\end{array}$ \\
\hline $\begin{array}{l}\text { Młodzież } \\
\text { (11-14 lat) } \\
\text { i dorośli }\end{array}$ & $\begin{array}{l}\text { gry sportowe, } \\
\text { siatkówka, } \\
\text { koszykówka, tenis, } \\
\text { tenis stołowy, jazda } \\
\text { na rowerze, jazda } \\
\text { na łyżwach, na } \\
\text { wrotkach (rolkach), } \\
\text { jazda na nartach, } \\
\text { skate boarding }\end{array}$ & $\begin{array}{l}\text { boisko sportowe, place do gier wspólnych } \\
\text { (siatkówka, koszykówka), miasteczko rowerowe } \\
\text { (edukacja bezpieczeństwa drogowego), mini } \\
\text { golf, korty tenisowe, urządzenia gimnastyczne, } \\
\text { pająki, trampoliny i batuty, ścianki wspinaczkowe, } \\
\text { mostki - równoważnie, ścieżki rowerowe i szlaki } \\
\text { narciarskie, zaawansowany skate park i snow } \\
\text { park, zielone siłownie, miejsca do wypoczynku, } \\
\text { stoły do gry w ping-ponga, stoły do szachów } \\
\text { i gier planszowych, lodowisko, góra saneczkowa, } \\
\text { siłownia plenerowa, place trawiaste do kąpieli } \\
\text { słonecznych, miejsca piknikowe, świetlica (sala } \\
\text { rekreacyjna, kawiarnia z toaleta wypożyczalnia } \\
\text { sprzętu sportowego), ławeczki do wypoczynku, } \\
\text { stoliki, oświetlenie }\end{array}$ \\
\hline Osoby starsze & $\begin{array}{l}\text { spacery, jazda na } \\
\text { rowerze, jazda na } \\
\text { nartach, wspólne } \\
\text { gry zespołowe, } \\
\text { spokojny } \\
\text { wypoczynek }\end{array}$ & $\begin{array}{l}\text { alejki spacerowe, zacienione miejsca do spokojnego } \\
\text { wypoczynku, ścieżki rowerowe, trasy do nart biego- } \\
\text { wych, boiska do gier, stoły do ping-ponga, stoły do } \\
\text { gry w szachy i warcaby lub planszówki, mini golf, } \\
\text { miejsce do gry w bule, alejki do nordic walking, } \\
\text { zielone siłownie, leżanki parkowe w miejscach } \\
\text { słonecznych i zacienionych, świetlica (sala } \\
\text { rekreacyjna, kawiarnia z toaleta, wypożyczalnia } \\
\text { sprzętu sportowego), ławeczki do wypoczynku, } \\
\text { stoliki, oświetlenie }\end{array}$ \\
\hline
\end{tabular}


Nie zawsze jednak, w pobliżu miejsca zamieszkania, takie oczekiwania mogą być zaspokojone, wiele spośród miejskich osiedli nie ma nic do zaoferowania poza niewielkim skwerkiem i skromnym placem zabaw, pozbawionym odpowiednich urządzeń dla starszych dzieci i młodzieży, gdzie dla osób dorosłych przewidziano jedynie ławeczki do spokojnego wypoczynku. Pomimo znacznej poprawy w ciągu ostatnich trzech dekad, dzięki rewitalizacji parków miejskich, modernizacji placów zabaw na osiedlach, zakładaniu „zielonych siłowni", poprawy bezpieczeństwa terenów sportu i wypoczynku, potrzeby rekreacyjne mieszkańców miast wciąż nie są zaspokojone w dostatecznym stopniu. Z przytoczonych opinii użytkowników, analizy stanu zagospodarowania placów zabaw, ich lokalizacji i programu funkcjonalnego wynika, że problem opustoszałych skwerów osiedlowych przegrywających z centrum handlowym lub grami na komputerze leży w nieprzystawaniu większości osiedlowych placów zabaw do rzeczywistych potrzeb i oczekiwań, ich niskiej atrakcyjności. Co jednak należy podkreślić, zarówno w opinii użytkowników (analiza materiału wywiadów) jak i fachowców w tej dziedzinie [Czałczyńska-Podolska 2017; Komorowska 2017] place zabaw są obecnie zdecydowanie bardziej bezpieczne, spełniające wymagane prawem kryteria [Norma PN EN 1176, Norma PN EN 1177; Yearley, Berliński 2008]. Porównując materiał badań terenowych z lat 2008-2010 (projekt ds.-114 AWF), powtórzony po dziesięciu latach na wybranych placach zabaw w Warszawie w ramach projektu ds.-300 AWF w latach 2017-2019, można stwierdzić, że przynajmniej na części z nich urządzenia terenowe są zdecydowanie bardziej urozmaicone i estetyczne, natomiast na wszystkich - zieleń znacznie uboższa (przede wszystkim zlikwidowano trawiaste podłoża i wycięto krzewy wskutek obawy zagrożenia ze strony kleszczy).

Zatem mamy do czynienia wyraźnie zarówno z problemem braku obszernych terenów zieleni w pobliżu miejsca zamieszkania, ale także z ich niedostatecznym przygotowaniem do aktywności fizycznych, mało atrakcyjnym programem. Odnosi się to zarówno do nowo powstałych osiedli (przy ulicy Rydygiera w Warszawie), ale również od dawna istniejących (przy ulicy Krajewskiego w Warszawie). Obecnie, z różnych przyczyn, najczęściej finansowych, place zabaw są zakładane na niewielkich spłachetkach ziemi między wysokimi domami, zaplanowane na podstawie tych samych rozwiązań co w sąsiednim „blokowisku”, nudne i monotonne w swojej powtarzalności, bez uwzględniania lokalnej tradycji i tożsamości miejsca, oczekiwań lokalnej społeczności. Nic dziwnego, że w takich warunkach z osiedlowego skweru korzysta przeciętnie tylko co dziesiąty mieszkaniec i to na krótko, a ponad połowa ankietowanych przez nas dzieci i opiekunów narzekała na brak atrakcyjnej oferty programowej i korzystała z obiektów oddalonych od domu. Niewątpliwie istnieje potrzeba zakładania zintegrowanych (uniwersalnych, wspólnych) terenów sportu i wypoczynku, umożliwiających zabawę i wypoczynek całej rodziny. Idea osiedlowych parków wychowania fizycznego o bogatym, zróżnicowanym programie nie jest nowa i warto do niej znów sięgnąć [Piątkowska i in. 1976; Pomorski, Poskrobko 1998; Wirszyłło 1986]. Program i sposób urządzenia takich terenów powinien uwzględniać potrzeby wielopokoleniowej rodziny, umożliwić aktywny wypoczynek: dzieciom małym, starszym, młodzieży, osobom dojrzałym i w wieku starszym - czyli trzem generacjom mieszkańców. 
Tu należy wtrącić, że recepta wydaje się tylko z pozoru prosta. Truizmem jest twierdzenie, że potrzeba naszym miastom więcej terenów zieleni i lepiej urządzonych. Dla uzyskania satysfakcjonujących, pod względem programu, terenów sportu i rekreacji niezbędne jest jednak spełnienie dwóch warunków:

- dysponowanie terenami wolnymi od zabudowy w pobliżu osiedli mieszkaniowych,

- dysponowanie środkami pozwalającymi na urządzenie terenu sportu i wypoczynku oraz utrzymanie go w należytym stanie.

Jest to możliwe do osiągnięcia tylko przez zwiększanie udziału terenów zielonych w ogólnym bilansie terenu osiedla, czyli wyższymi kosztami realizacji osiedli (przekładającymi się na wyższy koszt zakupu mieszkań) oraz przez zwiększanie opłat administracyjnych ponoszonych przez mieszkańców dla uzyskania środków na ich utrzymanie. Nie ma wątpliwości, że dla współczesnej rodziny takie rozwiązanie jest najkorzystniejsze, ale jego realizacja wymaga po pierwsze gruntownej korekty obowiązujących przepisów (w tym Rozporządzenia MI w sprawie warunków technicznych, jakim powinny odpowiadać budynki i ich usytuowanie z dnia 12 kwietnia 2002 r.), a po drugie zgody społecznej na wprowadzenie takich rygorów prawnych i konsekwencji finansowych z nich wynikających. Wymaga to przekonania społeczności do konieczności ponoszenia dodatkowych obciążeń, także z własnej kieszeni. Nie są to koszty małe: aby zapewnić przynajmniej $15 \mathrm{~m}^{2}$ (zalecane, bo optymalne $\mathrm{w}$ warunkach wielkomiejskich, jest nawet 35-40 $\mathrm{m}^{2}$ ) terenów zieleni osiedlowej na jednego mieszkańca, należy liczyć się, na dużych i ludnych osiedlach, z terenem o powierzchni nawet $5000 \mathrm{~m}^{2}$. Można więc łatwo policzyć, o ile by wzrosła cena 1 metra kwadratowego mieszkania i jak znacznie podwyższone byłyby tzw. miesięczne opłaty administracyjne, niezbędne do uzyskania środków na utrzymanie obszernego terenu sportu i wypoczynku w należytym stanie.

Istotny jest zatem element edukacji i informacji, aby skutecznie do takiego rozwiązania przekonać mieszkańców osiedla, którzy z osiedlowego parku będą co prawda korzystać, ale zwiększone obciążenie finansowe będę zmuszeni ponosić. Być może dobrym wyjściem dla ograniczenia kosztów jest propagowanie ponadosiedlowych terenów zieleni, służących kilku sąsiednim wspólnotom i współfinansowanych przez budżet gminy lub granty Unii Europejskiej. Możliwym rozwiązaniem jest łączenie terenów osiedlowej rekreacji, tak jak to było w przeszłości naszych miast nieraz praktykowane, z Rodzinnymi Ogrodami Działkowymi lub ogrodami dydaktyczno-rekreacyjnymi zakładanymi przy placówkach oświaty (popularnymi w okresie II RP, obecnie niestety likwidowanymi) [Dudek-Klimiuk 2019; Pawlikowska-Piechotka 2019]. Kolejną możliwością jest inspiracja i sięgnięcie do modelu coraz bardziej powszechnych w miastach Europy Zachodniej „urban farms” [Solarek 2019]. Statystyka wyborów w ramach budżetu obywatelskiego dowodzi, że na ten cel mieszkańcy chętnie głosują. Inaczej zgoła ma się rzecz z decyzją zakupu mieszkania droższego, ale mającego obszerne tereny zieleni oraz deklaracją zgody na podwyższone opłaty administracyjne, pozwalające na lepsze urządzenie terenów rekreacji osiedlowej. Ze względu na istotną barierę finansową, wiele młodych rodzin decyduje się na zamieszkanie poza miastem, gdzie 
dostęp do terenów sportu i rekreacji jest łatwiejszy, ale uzyskany kosztem uciążliwych dojazdów do pracy i szkoły9

Jak powinien być urządzony plac zabaw - odpowiedzi jednej, w formie uniwersalnej rekomendacji być nie może, ponieważ każda lokalizacja terenu rekreacji osiedlowej jest inna, różne są uwarunkowania finansowe i terenowe, odmienne oczekiwania społeczności lokalnej (tabela 1). Nowe potrzeby w zakresie aktywnego wypoczynku są konsekwencją zmian w samym społeczeństwie miejskim, różniącym się znacząco od poprzednich generacji. W ciągu ostatnich trzech dekad (w latach 1989-2018) doszło nie tylko do zmian na rynku pracy, zmian ekonomicznych, zmian demograficznych (widocznych w nowej strukturze gospodarstw domowych), ale i w sposobach spędzania czasu wolnego. Aby spełnić te oczekiwania, bardzo ważne z punktu widzenia promocji zdrowia, należy zapewnić odpowiedniej wielkości, właściwie urządzone - w sposób inkluzyjny i uniwersalny z myślą o całej rodzinie - otwarte tereny rekreacji w środowisku zurbanizowanym. Zatem niezbędnym elementem przygotowań planowanej inwestycji powinny być zawsze rzetelnie przeprowadzone konsultacje społeczne. Przyszli użytkownicy powinni być obecni przy wszystkich etapach planowania i realizacji projektu, a są to:

1. Inwentaryzacja stanu istniejącego, tworzenie baz danych, badania społeczne preferencji przyszłych użytkowników, opracowanie standardów, szacunki ekonomiczne.

2. Planowanie zagospodarowania na podstawie zgromadzonego materiału inwentaryzacji i baz danych, rekomendacji programowych i zaleceń, uwarunkowań prawnych; uwzględnienie elastyczności rozwiązań, prezentacja projektu lokalnej społeczności, konsultacje branżowe i społeczne, dyskusja.

3. Realizacja projektów, angażowanie lokalnej społeczności w proces tworzenia miejsca wypoczynku, promocja.

4. Zarządzanie, utrzymanie w przyjętych standardach, organizacja imprez i zajęcia animacji, popularyzacja różnych form aktywnego wypoczynku i zdrowego stylu życia, monitoring potrzeb i diagnoza ewentualnych konfliktów, łagodzenie sporów, wprowadzanie nowych urządzeń i form użytkowania.

\footnotetext{
${ }_{9}^{9}$ W czasie badań terenowych ds.-300 AWF (2016-2018) jednym z pytań kierowanych do naszych respondentów było „Czy jest Pan/Pani gotów płacić wyższy czynsz, aby tereny rekreacji osiedlowej były bardziej atrakcyjne?" Odpowiedzi były w 90\% przypadków zdecydowanie negatywne, argumentowane komentarzami na temat konieczności spłat rat kredytu bankowego oraz i tak już ocenianymi jako zbyt wysokie opłatami czynszowymi. Z przeglądu warszawskich ofert deweloperskich z kolei wiadomo, że mieszkania na osiedlach o bardziej obszernych i lepiej urządzonych terenach rekreacji są albo zlokalizowane zdecydowanie peryferyjnie, poza granicami administracyjnymi Warszawy, albo przy lokalizacji w granicach miasta znacznie droższe, wyższe także są na nich przyszłe opłaty tzw. administracyjne (sierpień 2019). Niezmiennie odpowiedzią na pytanie - kto powinien być odpowiedzialny finansowo za te inwestycje wskazy wane są instytucje rządowe, samorządowe i enigmatycznie "administracja osiedla" (ale bez obciążania finansowego mieszkańców). Co ciekawe, inaczej wyglądały odpowiedzi na to samo pytanie w czasie badań wcześniejszych ds.-114 AWF (2008-2011), wówczas $70 \%$ respondentów deklarowało gotowość ponoszenia wyższych opłat w zamian za lepiej urządzone tereny wypoczynkowe osiedla.
} 
Obecnie, jakże słusznie narzekamy na coraz mniejszą aktywność fizyczną dzieci i młodzieży, których konsekwencją są identyfikowane narastające problemy zdrowotne występujące w młodym pokoleniu: cukrzyca, nadwaga i otyłość, problemy krążenia, wady postawy [Dąbrowski 2006; Woolley 2012; Wyrzykowski 2000].

Autorki pragną jednak podkreślić, że w programach promocji zdrowia i zachowań prozdrowotnych konieczna jest konsekwencja. Trudno bowiem kształtować pożądane postawy aktywnego wypoczynku, realizować z przekonaniem hasła „sportu dla wszystkich”, ,sportu w rodzinie", "zdrowego trybu życia”, jeżeli zabraknie w pobliżu osiedli mieszkaniowych właściwych warunków (terenów i urządzeń) niezbędnych do ich realizacji - w postaci uniwersalnych, inkluzyjnych placów sportu i zabaw, atrakcyjnych funkcjonalnie i programowo dla przedstawicieli trzech pokoleń o różnym stopniu sprawności fizycznej i zainteresowaniach.

Prezentowany materiał oparto na dorobku materiału badań projektu statutowego ds.-300 (z lat 2016-2019), na temat historycznych i współczesnych warunków aktywnego wypoczynku dzieci w środowisku zurbanizowanym. Projekt były realizowane na Akademii Wychowania Fizycznego Józefa Piłsudskiego w Warszawie przy współpracy Instytutu Matki i Dziecka w Warszawie, na podstawie grantów Ministerstwa Nauki i Szkolnictwa Wyższego.

\section{Literatura}

Czałczyńska-Podolska M., 2017, Rekreacja na osiedlach, Zieleń Miejska, 3, s. 272-326.

[e-czytelnia.abrys.pl, dostęp: czerwiec 2017].

Daly J., 2000, Recreation and Sport. Planning and Design, Human Kinetics, Leeds.

Dąbrowski A., 2006, Uczestnictwo Polaków w rekreacji ruchowej i jego uwarunkowania, Akademia Wychowania Fizycznego Józefa Piłsudskiego, Warszawa.

Dudek-Klimiuk J., 2019, Ogrody szkolne w Polsce międzywojennej, Wydawnictwo Naukowe Semper, Warszawa.

European Playground Safety Standards, 1999, EN 1176 and EN 1177, EU Brussels, Brussels.

Gaventa S., 2006, New Public Spaces, CABE SPACE, London.

Komorowska A., 2017, Absurdy oraz innowacje na polskich placach zabaw, Zawód Architekt, 56, s. 052-060.

Maszczak T., 2019, Kultura fizyczna osób niepetnosprawnych - misja i etos [w:] Z. Dziubiński (red.), Kultura fizyczna a etos, Akademia Wychowania Fizycznego Józefa Piłsudskiego, Warszawa, s. 291-299. 
Nowak Z., 1997, Wymagania i zasady kształtowania integracyjnych placów zabaw dla dzieci przy uwzględnianiu potrzeb dzieci niepetnosprawnych, Centralny Ośrodek Badawczo-Projektowy Budownictwa Ogólnego, Warszawa.

Ostrowska A., Nałęcz H., Pawlikowska-Piechotka A., 2019, Tradycja placów zabaw w Polsce i w Europie, MAZOWSZE Studia Regionalne, 31, s. 11-37.

Pawlikowska-Piechotka A., 2010, Urban Outdoor Recreation: Children's Playgrounds, Studies in Physical Culture and Tourism, 17, 4, University School of Physical Education in Poznań, s. 375- 85 .

Pawlikowska-Piechotka A., 2011, Przestrzeń rekreacji dziecka w mieście, Novae Res, Gdynia.

Pawlikowska-Piechotka A., 2012, Europejskie tradycje rekreacji w mieście, Akademia Wychowania Fizycznego Józefa Piłsudskiego, Warszawa.

Pawlikowska-Piechotka A., 2016, Przestrzeń sportu, rekreacji i turystyki bez barier, Akademia Wychowania Fizycznego Józefa Piłsudskiego, Warszawa.

Pawlikowska-Piechotka A., 2019, Rodzinne ogrody działkowe w Warszawie. Tradycja i współczesność, MAZOWSZE Studia Regionalne, 29, s. 67-79.

Pellegrini A.D., Bohn-Gettler C.M., 2013, The Benefits of Recess in the Primary School, Scholarpedia, 8, 2, 30448 .

Piątkowska K, Scholtz A, Wirszyłło R., 1976, Rekreacja w osiedlu, Zakład Wydawnictwa CRS, Warszawa.

Pomorski J., Poskrobko W., 1998, Ksztattowanie terenów zieleni, Wydawnictwa Szkolne i Pedagogiczne, Warszawa.

Rice L., 2009, Everyday Urbanism and Play, Journal of Planning and Architecture, 2, s. 53-55.

Risotto A., 2012, Projects and Policies for Childhood in Italy [w:] Culture, Environment Action and Sustainability, International Association of People Environment Studies IAPS, Gottingen, s. 203-211.

Rojek Ch., Show S. M., Veal A. J., 2007, A handbook of Leisure Studies, Palgrave Macmillan, New York.

Sawyer Th. H., 2009, Facilities Planning for Health, Fitness, Physical Activity, Recreation and Sports (12. wyd.), Sagamore Publishing, Urbana, USA.

Solarek K. (red.), 2017, Miasto dostępne jako jedno z wyzwań planowania zintegrowanego, Studia KPZK PAN, 176, Komitet Przestrzennego Zagospodarowania Kraju PAN, Warszawa.

Solarek K., 2019, Urban Design in Town Planning. Current Issues and Dilemmas from the Polish and European Perspective, Oficyna Wydawnicza Politechniki Warszawskiej, Warszawa.

Wirszyłło R., 1986, Obiekty sportowe, Wydawnictwo ARKADY, Warszawa. 
Woolley H. E., 2003, Urban Open Spaces, Taylor \& Francis, London-New York.

Woolley H.E., 2012, Now Being Social: The Barrier of Designing Outdoor Play Spaces for Disabled Children, Children and Society, 27, 6, s. 448-458.

Woolley H.E., Lowe A., 2013, Exploring the Relationship between Design Approach and Play Value of Outdoor Play Spaces, Landscape Research, 38, 1, s. 53-74.

Woolley H.E., Griffin E., 2015, Decreasing experiences of home range, outdoor spaces, activities and companions: changes across three generations, Children's Geographies, 13, 6, s. 677-691.

Wyrzykowski J. (red.), 2000, Studia nad czasem wolnym mieszkańców dużych miast Polski i jego wykorzystanie na rekreacje ruchowa, AWF Wrocław, Wrocław.

Yearley D., Berliński D., 2008, Bezpieczny plac zabaw, Urząd Ochrony Konkurencji i Konsumentów, Londyn-Warszawa.

\section{Akty prawne}

Dyrektywy UE nr 2001/95/WE, w polskich regulacjach prawnych wprowadzona ustawą z dnia 12 grudnia 2003 r. o ogólnym bezpieczeństwie produktów (Dz.U. z 2003 r. nr 229 z późn. zm.).

Norma PN EN 1176 w sprawie wyposażenia placów zabaw i nawierzchni.

Norma PN EN 1177 w sprawie nawierzchni amortyzujących upadki.

Rozporządzenia Ministra Infrastruktury w sprawie warunków technicznych, jakim powinny odpowiadać budynki i ich usytuowanie z dnia 12 kwietnia 2002 r. (Dz.U. z dnia 7 czerwca 2019 r. poz. 1065).

Ustawa Prawo Budowlane z dnia 7 lipca 1994 r. (Dz.U. z 1994 r. nr 89 z późn. zm.).

\section{Strony internetowe}

www.tustolica.pl [dostęp: luty 2020]

www.zahahadid.architects [dostęp: wrzesień 2016] 


\section{Urban playgrounds for everyone and not just for children}

\section{ABSTRACT}

While in the past playgrounds were usually designed for children, today we can observe more sports and recreation facilities dedicated to all age groups, including seniors. Traditional playgrounds are fitted for the youngest users and contain recreational equipment such as seesaws, slides and merry-gorounds. The playgrounds of universal character have also facilities for adults, such as a basketball court or a chess board. These enable families to play together, develop physical coordination, strength, flexibility, self-esteem and social skills, as well as providing recreation and enjoyment. On the basis of public playgrounds located in Warsaw the authors tried to answer the following questions: which facilities help stimulating and developing social, mental and physical skills and what are the most frequent users suggestions for improvements. With the use of the field survey (participant observations, structured and semi-structured interviews), a number of subjective and objective factors, which might determine the 'inclusive urban playground', were identified. Strong and weak points of the playgrounds were indicated (their accessibility, layout design, safety level and attractiveness of equipment). The correlation between available equipment and gender, age group, physical and mental stimulation was investigated, based on set criteria. Universally designed, inclusive playgrounds (for all age groups) should be accessible to all community members, including seniors and persons with disabilities. To achieve this, basic principles must be followed: accessibility, infrastructure designed for users of different physical abilities and age, adapted to the expectations and interests of the local community. As it shows, exciting, engaging and challenging playground equipment and accessible sports and recreation facilities are important to encouraging physical activities, integration and strengthening social bonds. The paper is based on the statuary research project ds-300 AWF, which was undertaken on the Józef Piłsudski University of Physical Education in Warsaw, on the base of the Ministry of Science and Higher Education grant.

Key words: recreation for three generations, child and urban environment, sports and recreation facilities

\footnotetext{
$\overline{\text { Anna Ostrowska-Tryzno }-d r ~ n a u k ~ o ~ k u l t u r z e ~ f i z y c z n e j, ~ a d i u n k t ~ n a ~ W y d z i a l e ~ W y c h o w a n i a ~ F i z y c z n e g o ~ A W F ~ w ~ W a r s z a w i e . ~ S p e c j a l i-~}$ zuje się w problematyce zrównoważonego rozwoju miast oraz odpowiedzialnej turystyce biznesowej. Aktualnie koncentruje swoja aktywność badawczą na zagadnieniach dotyczących plenerowej infrastruktury sportowo-rekreacyjnej w miastach, dostępnej dla dzieci i młodzieży, osób starszych oraz osób z niepełnosprawnościami.

e-mail:anna.tryzno@awf.edu.pl

Anna Ostrowska-Tryzno - PhD in physical culture, works at the Faculty of Physical Education at the Józef Piłsudski University of Physical Education in Warsaw. She specializes in sustainable urban development and responsible business tourism. She is currently focusing her research activity on issues related to outdoor sports and recreation infrastructure in cities, accessible for children and youth, the elderly and people with disabilities.

e-mail: anna.tryzno@awf.edu.pl
}

Hanna Nałęcz - pedagog, specjalista zdrowia publicznego, dr nauk o kulturze fizycznej; ukończyła studia magisterskie na Wydziale Pedagogiki Uniwersytetu Warszawskiego, studia pierwszego stopnia w dziedzinie zdrowia publicznego w Akademii Medycznej im. K. Marcinkowskiego w Poznaniu (2009), uzyskała stopień doktora nauk o kulturze fizycznej na Wydziale Wychowania Fizycznego Akademii Wychowania Fizycznego w Warszawie (2010). Jest certyfikowanym edukatorem edukacji zdrowotnej i promocji zdrowia MEN (2008), ukończyła ponadto kursy w kierunku edukacji zdrowotnej w kraju i zagranica. Staż naukowy odbyła na Uniwersytecie w Limerick, Irlandia - Wydział Education \& Health Sciences (2014). Od 2006 r. pracuje w Instytucie Matki i Dziecka w Warszawie, obec- 


\section{PLACE ZABAW W MIEŚCIE - DLA WSZYSTKICH A NIE TYLKO DLA DZIECI \\ Hanna Nałęcz, Anna Ostrowska-Tryzno, Anna Pawlikowska-Piechotka}

nie w Zakładzie Zdrowia Dzieci i Młodzieży IMiD. Uczestnik krajowych i międzynarodowych badań, konsultant naukowy w krajowych i międzynarodowych projektach badawczych, ukierunkowanych na aktywność fizyczna dzieci, młodzieży i dorosłych. Jest autorem i współautorem ponad 70 publikacji naukowych krajowych i zagranicznych (w tym w czasopismach z Listy Filadelfijskiej) oraz doniesień konferencyjnych, dotyczących aktywności fizycznej, psychospołecznych uwarunkowań zdrowia i zachowań zdrowotnych dzieci, młodzieży i dorosłych.

Kontakt: Instytut Matki i Dziecka, adiunkt w Zakładzie Zdrowia Dzieci i Młodzieży, Warszawa;

e-mail: hanna.nalecz@imid.med

Hanna Nałęcz, PhD-teacher, public health specialist, PhD in physical culture sciences; she graduated from the Faculty of Pedagogy at the University of Warsaw, completed the undergraduate studies in Public Health at the Medical Academy K. Marcinkowski in Poznań (2009), obtained a PhD degree in physical culture at the Faculty of Physical Education at the Józef Piłsudski University of Physical Education in Warsaw (2010). She is a certified MEN educator in health education and health promotion (2008), she also completed several courses in health education in Poland and abroad. She took an internship at the University of Limerick, Ireland - Faculty of Education \& Health Sciences (2014). Since 2006 she has been working at the Institute of Mother and Child in Warsaw, currently at the Department of Child and Adolescent Health. Participant of national and international research projects, scientific consultant in national and international research projects focused on physical activity of children, youth and adults. She is the author and co-author of over 70 scientific publications (including journals listed on ISI Master Journal List) and conference reports on physical activity, psychosocial determinants of health and health behaviours of children, youth and adults published in Poland and abroad.

Contact: Institute of Mother and Child, assistant professor at the Department of Child and Adolescent Health, Warsaw; e-mail: hanna.nalecz@imid.med

Anna Pawlikowska-Piechotka, prof. dr hab. inż. arch. - architekt i urbanista, w latach 2004-2014 profesor wizytujq̨cy na University College Birmingham (Wielka Brytania), Charles University of Prague (Czechy), University of Lahti (Finlandia), University of Saragossa (Hiszpania), University of Evora (Portugalia), University of Viseau (Portugalia), Holar University (Islandia). W swoich badaniach koncentruje się na wykorzystaniu dziedzictwa kulturowego dla zrównoważonego rozwoju turystyki i odpowiedzialnego planowania przestrzeni turystyki, sportu i rekreacji. Uczestniczyła w kilku międzynarodowych projektach badawczych (Niemcy, Szwecja, Holandia, Wielka Brytania, Polska, Turcja); jest autorem ponad dwustu publikacji naukowych, w tym kilku monografii, tekstów opublikowanych w języku angielskim, niemieckim, polskim i serbskim; współautor kilkudziesięciu planów architektonicznych i urbanistycznych (zrealizowanych w Polsce, Niemczech, Nigerii i Libii) oraz wzorów użytkowych obiektów rekreacyjnych dla osób niepełnosprawnych - formalnie zarejestrowanych w Urzędzie Patentowym RP.

Kontakt: Akademia Wychowania Fizycznego Józefa Piłsudskiego w Warszawie;

e-mail:anna.piechotka@gmail.com

Anna Pawlikowska-Piechotka, professor, PhD Eng Arch. - architect and urban planner, in 2004- 2014 a visiting professor at University College Birmingham (United Kingdom), Charles University of Prague (Czech Republic), University of Lahti (Finland), University of Saragossa (Spain), University of Evora (Portugal), University of Viseau (Portugal), Holar University (Iceland). In her research, she focuses on the usage of cultural heritage for sustainable tourism and responsible planning for tourism, sport and recreation. She participated in several international research projects (Germany, Sweden, Holland, UK, Poland, Turkey); she is the author of over two hundred scientific publications, including several monographs, papers published in English, German, Polish and Serbian; co-author of several architectural and urban plans of recreation and tourist space (commissioned in Poland, Germany, Nigeria and Libya) and utility models of recreation facilities for disabled - formally registered in the Polish Patent Office.

Contact: the Józef Piłsudski University of Physical Education in Warsaw;

e-mail:anna.piechotka@gmail.com 